\title{
Diagnostic value of advanced semen analysis in evaluation of male infertility
}

\author{
Cătălina Barbăroșie ${ }^{1,2}$ (D) | Ashok Agarwal ${ }^{1}$ (D) | Ralf Henkel ${ }^{1,3}$ (D)
}

\author{
${ }^{1}$ American Center for Reproductive \\ Medicine, Cleveland Clinic, Cleveland, $\mathrm{OH}$, \\ USA \\ ${ }^{2}$ Department of Genetics, Faculty of Biology, \\ University of Bucharest, Bucharest, Romania \\ ${ }^{3}$ Department of Medical Bioscience, \\ University of the Western Cape, Bellville, \\ South Africa
}

\section{Correspondence}

Ashok Agarwal, Mail Code X-11, 10681

Carnegie Avenue, Cleveland, $\mathrm{OH} 44195$, USA.

Email: agarwaa@ccf.org

\begin{abstract}
Conventional semen analysis is the standard of care to initially evaluate the fertility status of a male patient. However, it has some limitations and among these are failure to correctly identify the aetiology underlying fertility problems, intra- and interobserver variability and incomplete information about sperm function. Considering these drawbacks, advanced semen tests have been developed to assess male infertility, including sperm function tests, oxidative stress (OS) and sperm DNA fragmentation (SDF) tests. This review illustrates the commonly utilised sperm function techniques, along with the assays used to assess SDF and OS and their diagnostic value.
\end{abstract}

\section{KEYWORDS}

diagnostic value, male infertility, oxidative stress, sperm DNA fragmentation, sperm function tests

\section{1 | BACKGROUND}

Couples who are unable to conceive within a year of regular, unprotected sexual intercourse are recommended to seek evaluation. In about $40 \%$ of the couples, infertility is caused by a male factor and by both partners in an additional $20 \%$ of couples. The underlying causes for male infertility are multifactorial, with about $20 \%$ of these cases being idiopathic (Ayaz et al., 2015; Louis et al., 2013).

\section{1 | Overview of semen analysis and its implications}

According to the guidelines of the World Health Organization (WHO, 2010), the clinical evaluation of male patients includes a medical history, physical examination and at least two semen analyses. The conventional semen analysis is very important in identifying the severity of male factor infertility and guiding future analysis and treatment (Agarwal \& Bui, 2017). It further includes the determination of volume, $\mathrm{pH}$, colour, viscosity, liquefaction time, number of round cells, sperm total count, concentration, motility and normal sperm morphology.

\subsection{Limitations of semen analysis in predicting fertility status}

Although standard semen analysis remains the standard of care to initially evaluate male patients with infertility, a routine semen analysis does not accurately identify the aetiology of infertility or predict the reproductive success (Snow-Lisy \& Sabanegh, 2013). Routine semen analysis yields variable results due to inter- and intra-observer variability, and it gives no information about sperm dysfunctions at cellular and molecular levels (Agarwal \& Bui, 2017; Esteves, 2014). Moreover, the lower reference limits established by the WHO are not applicable to all men as values of semen parameters overlap in fertile and infertile men. Therefore, the exact cause of idiopathic and unexplained male infertility remains unknown, even after performing routine semen analysis (Hamada, Esteves, \& Agarwal, 2011; Wallach et al., 1983). Normal semen parameters do not equate with a normal fertilisation potential of spermatozoa (Hamada et al., 2011; Lewis, 2007). As a consequence, more advanced tests are needed to accurately diagnose male infertility and predict pregnancy in couples trying to conceive naturally or couples undergoing assisted reproductive technologies (ART; Oehninger, Franken, \& Ombelet, 2014). 


\subsection{What additional information can sperm function tests provide?}

When investigating male factor infertility, it is important to consider the detrimental effects of sperm chromatin and DNA damage. Identifying sperm dysfunctions and predicting fertilisation and pregnancy rates are potential benefits of sperm function tests (Oehninger et al., 2014). Sperm function tests are able to assess the transport of spermatozoa to the oocyte, the interaction of spermatozoa with cervical mucus and sperm-oocyte interaction. These tests assess the completion of sperm capacitation and the ability of spermatozoa to undergo ligand-induced acrosome reaction. Furthermore, sperm function tests determine whether spermatozoa are mature, motile and able to bind to hyaluronan (Kızlay \& Altay, 2017). These aspects are crucial for the success of the fertilisation (Hamada et al., 2011; Oehninger et al., 2014). Also, sperm function tests could indicate an appropriate therapy to overcome the fertility problems (Kızlay \& Altay, 2017).

\section{SPERM FUNCTION}

\section{1 | Physiological basis of achieving fertilisation, pregnancy and embryonic development}

Both, spermatozoa and oocytes undergo a series of preparatory steps to achieve fertilisation. The fertilisation process takes place once a spermatozoon reaches, recognises, binds and enters the oocyte (Lewis, 2007). This process involves sperm capacitation, penetration of the oocyte's cumulus matrix and acrosomal exocytosis (Ikawa, Inoue, Benham, \& Okabe, 2010). During acrosomal exocytosis, hundreds of fusion pores are formed between the outer acrosomal membrane and the sperm head plasma membrane. As a result, the enzymes released from the acrosome locally digest the oocyte's zona pellucida. Consequently, a spermatozoon penetrates the zona pellucida, attaches to the oolemma, the oocyte plasma membrane, and delivers the paternal genome to the future embryo (Anifandis, Messini, Dafopoulos, Sotiriou, \& Messinis, 2014; Evans \& Bailey, 2010). With each stage of the sperm transit through the female genital tract, the number of spermatozoa decreases, and only the most viable and capable spermatozoon reaches the oocyte. Oocytes will eventually only be fertilised by a single spermatozoon.

\section{3 | SPERM FUNCTION TESTS}

\section{1 | Capacitation}

Spermatozoa undergo a capacitation phase in the female genital tract. This physiological process involves all changes that enable spermatozoa to undergo acrosome reaction and thereby acquire fertilisation competence. A test to determine the spermatozoa's ability for capacitation aims to induce sperm capacitation under laboratory conditions by placing the spermatozoa in a capacitating medium (Ayaz et al., 2015; Louis et al., 2013) such as human tubal fluid (HTF) medium enriched with 3\% albumin (Agarwal, Gupta, \& Sharma, 2016a). A new test has been developed to assess the spermatozoa's capacitation potential, Cap-Score ${ }^{\mathrm{TM}}$ Sperm Function Test $\left(\right.$ Cap-Score $\left.{ }^{\mathrm{TM}}\right)$. The aim of this test is the detection and analysis of the localisation patterns of the ganglioside $\mathrm{G}_{\mathrm{M} 1}$ (a marker of lipid rafts in the sperm membrane), which is important for the evaluation of the spermatozoa's capacity to fertilise the oocyte. The proportion of spermatozoa that present the localisation patterns of the ganglioside $G_{M 1}$ that corresponds with capacitation is reported (Moody et al., 2017).

The clinical utility of the sperm capacitation test has not yet been well defined (Sigman \& Zini, 2009; Vasan, 2011). This test may be used as a diagnostic tool (Moody et al., 2017) as it significantly correlated with the probability of pregnancy and was able to predict high versus low pregnancy rates (Schinfeld et al., 2018). On the one hand, reactive oxygen species (ROS) at low concentrations are essential to trigger capacitation. However, an excessive intake of antioxidants could cause reductive stress, which can scavenge these essential ROS and thereby lead to male infertility (Henkel, Sandhu, \& Agarwal, 2019). In case of reductive stress, a discontinuation of the antioxidant intake would then be recommended. On the other hand, in cases of oxidative stress (OS), that is the excessive availability of ROS, premature capacitation (de Castro et al., 2016) and acrosome reaction (El-Taieb, Ali, \& Nada, 2015) would be triggered, a condition which can also lead to infertility. The reduction of the OS by eliminating its causes such as varicocele or the administration of antioxidants would be advised.

\subsection{Acrosome reaction}

The acrosomal reaction (AR) is a process that naturally occurs after sperm capacitation and sperm-zona pellucida binding. During AR, proteolytic enzymes stored in the acrosome are released to enable sperm-zona pellucida penetration eventually allowing spermatozoa to fertilise the oocyte (Agarwal, Bragais, \& Sabanegh, 2008).

There are a series of laboratory tests to assess the ability of spermatozoa to undergo AR such as flow cytometry and fluorescence microscopy using lectins or antibodies, electron microscopy, bright-field light microscopy and chlortetracycline fluorescence. In order to investigate acrosomal functionality, a baseline and an induced AR are determined (Figure 1; Kızılay \& Altay, 2017; Zeginiadou, Papadimas, \& Mantalenakis, 2000). AR testing assesses the percentage of spermatozoa that spontaneously release their acrosomal content as well as the percentage of spermatozoa that are acrosome-reacted after an induction of AR in vitro (Snow-Lisy \& Sabanegh, 2013). The difference between induced and spontaneous $A R$ is called the inducibility of $A R$, that is the ability of spermatozoa to undergo AR (Henkel, Müller, Miska, Gips, \& Schill, 1993). 


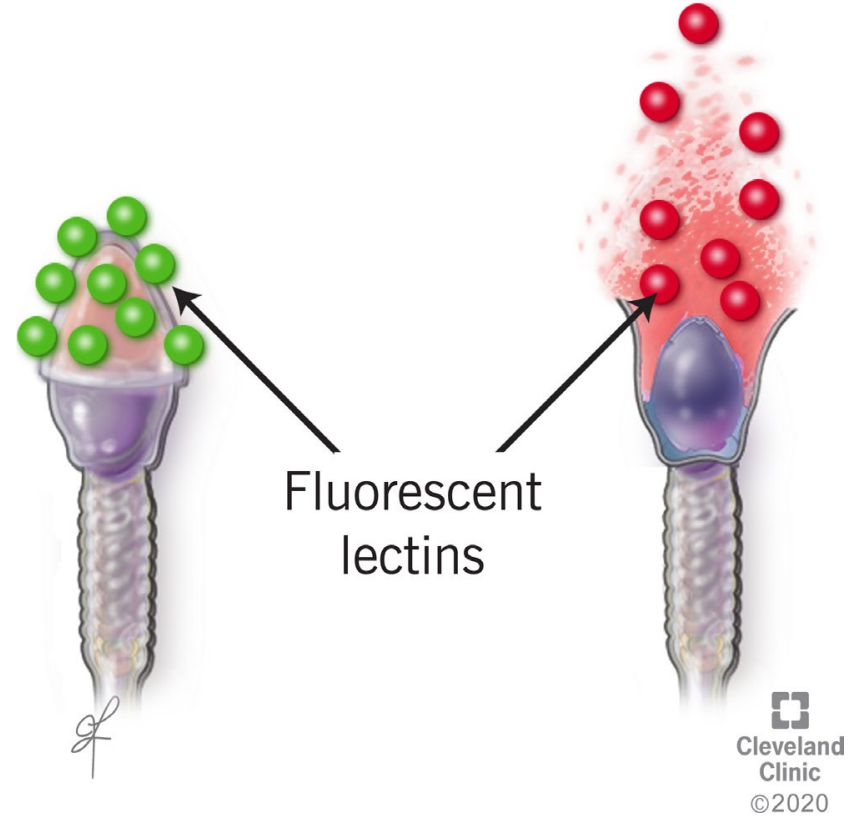

FIGURE 1 Acrosome reaction testing using lectins labelled with fluorescence (Reprinted with permission, Cleveland Clinic Center for Medical Art \& Photography (C2011-2020. All Rights Reserved)

Electron microscopy and flow cytometry are considered the best techniques for AR testing. However, their performance comes with a big disadvantage as both techniques are expensive. Other techniques are easier to perform, but have other disadvantages as they are labour-intensive and it can be difficult to properly identify the AR. Important information is gathered by distinguishing between spontaneous and AR following the induction with calcium ionophore or low temperature (Zeginiadou et al., 2000).

Overall, testing the AR can give valuable information regarding the fertilising ability of spermatozoa (Zeginiadou et al., 2000). Pampiglione, Tan, and Campbell (1994) concluded that an acrosomal response $<31.3 \%$ is an indicator of fertilisation failure in all studied cases. A meta-analysis concluded that AR is a good predictor of in vitro fertilisation (IVF) outcome (Oehninger, 2000). As a consequence, patients with ART failure and poor acrosomal reaction should be redirected to ICSI (KIzılay \& Altay, 2017). A more sophisticated test for $A R$ is the zona pellucida-induced acrosome reaction (ZIAR) induced by solubilised human zona pellucida (ZP) that can distinguish between fertile and subfertile males $(p=.001$; Bastiaan, Menkveld, Oehninger, \& Franken, 2002). In general, the information provided by AR testing helps in better managing the male infertility cases.

\section{3 | Sperm-zona pellucida binding tests}

To reach the oolemma and consequently the nucleus of the oocyte, spermatozoa must pass through the zona pellucida. The most common causes of IVF (Liu \& Baker, 2000) and intrauterine insemination (IUI; Arslan et al., 2006) failure are sperm-zona pellucida binding defects. The two most common tests that evaluate sperm-zona pellucida binding capacity are the hemizona assay (Oehninger et al., 1989) and the competitive zona binding assay (Liu, Clarke, Lopata, Johnston, \& Baker, 1989). Sperm-zona pellucida binding assays have a high predictive power for fertilisation outcome (Oehninger, 2000). These tests may be recommended for patients with standard IVF failure and unknown primary infertility causes (Samplaski, Agarwal, Sharma, \& Sabanegh, 2010). As a consequence, patients with sperm-zona pellucida binding defects are counselled to consider ICSI (Arslan et al., 2006).

\subsection{1 | Hemizona assay}

For the hemizona assay ( $\mathrm{HZA})$, either pre-ovulatory, non-fertilised or recycled failed-fertilised human oocytes can be used (Henkel, Müller, Stalf, Schill, \& Franken, 1999; Oehninger et al., 1991; Henkel et al., 1995). Since oocytes are dissected into two equal halves under microscopic control and the ooplasm is then removed, there is no functional, live oocyte for fertilisation, but an empty hemizona with no developmental potential. One hemizona is incubated with fertile donor spermatozoa (positive control), and the second half is incubated with patient's spermatozoa (Samplaski, Sharma, Agarwal, \& Sabanegh, 2014). The hemizona index (HZI), which is the ratio of patient and control, is calculated. A value of $\mathrm{HZI}<30 \%$ is considered abnormal (Arslan et al., 2006).

The hemizona assay can significantly distinguish between fertile and subfertile male patients ( $p=.001$; Bastiaan et al., 2002) and may be recommended to patients with oligoasthenoteratozoospermia (OAT) and with repetitive IVF failures (Oehninger et al., 2014). Patients with a $\mathrm{HZI}<30 \%$ had lower pregnancy rates compared with patients with a $\mathrm{HZI}$ more or equal to $30 \%(11.1 \%$ and $40.6 \%$, respectively; Arslan et al., 2006). Furthermore, patients with oligozoospermia have low or normal ZP binding, but low ZIAR (56/72, 78\%), which is in accordance with their low probability of natural or conventional IVF fertilisation rate (Liu \& Baker, 2004; Oehninger, 2000; Oehninger et al., 1989). This test is of high clinical value and gives important information regarding the physiology of the spermatozoa. However, due to its labour-intensiveness, the necessity for specialised expensive equipment and the fact that human zonae pellucidae are not readily available, the hemizona assay is rarely used today.

\subsubsection{Competitive intact zona binding assay}

For the competitive zona binding assay or sperm-zona binding ratio test, zona-intact devitalised human oocytes are used. About 20 zonae pellucidae of complete human oocytes are incubated with an equal number of motile spermatozoa from both fertile donor (control) and patient (test). The control and test spermatozoa are labelled with different fluorochromes. The cut-off value for the ratio of the number of test spermatozoa to that of control spermatozoa is $30 \%$, and a value of less than the 
cut-off is considered abnormal (Esteves, Verza, Sharma, Gosálvez, \& Agarwal, 2015). Regarding the competitive intact zona binding assay, Liu et al. (1989) concluded that the result of this test is correlated with the fertilisation rate in patients with abnormal sperm morphology.

\section{4 | Sperm-oocyte penetration assay}

The sperm-oocyte penetration assay or zona-free hamster oocyte penetration assay was one of the first assays to evaluate sperm function and tests the ability of spermatozoa to undergo capacitation, acrosome reaction, fusion and penetration through the oolemma. Furthermore, it tests the ability of sperm heads to decondense within the cytoplasm of hamster oocytes (Oehninger et al., 2014). Human spermatozoa undergo capacitation and bind to the oolemma of trypsinated hamster oocytes to remove the zona pellucida (Kızılay \& Altay, 2017).

This test poorly predicts fertilisation outcome (Oehninger, 2000). The sensitivity and specificity (Mao \& Grimes, 1988; Vogiatzi et al., 2013), positive and negative predictive values (PPV and NPV; Kızılay \& Altay, 2017; Mao \& Grimes, 1988; Vogiatzi et al., 2013) for this test widely vary. This test cannot predict successful IVF, and it is considered as insufficient for IVF patient selection (sensitivity $37 \%$, specificity 95\%; Mol et al., 1998). In conclusion, the sperm-oocyte assay is not recommended for routine use as it is an expensive and time-consuming test with a poor clinical value (Kızılay \& Altay, 2017).

\subsection{Other tests}

Additional tests that assess various sperm functions are the hypoosmotic swelling test, the sperm mitochondrial membrane potential, the hyaluronan binding assay and the anti-sperm antibodies test.

\subsection{1 | Hypo-osmotic swelling test}

Sperm vitality and plasma membrane integrity can be assessed with the hypo-osmotic swelling test (HOST; Agarwal, Gupta, \& Sharma, 2016b). A characteristic of viable spermatozoa with intact membrane under hypo-osmotic stress $(150 \mathrm{mOsmol} / \mathrm{L})$ is that they swell and curl their tail. This is a consequence of the membrane semi-permeability when fluid enters the cell's intact membrane. While live cells keep ions and other osmotically active molecules outside and only allow water to penetrate into the cell, resulting in cellular swelling, the plasma membrane of dead spermatozoa is not intact resulting in a leaky membrane. Consequently, dead spermatozoa do not swell and do not change their tail shape (Dias, Cho, \& Agarwal, 2019). Patients with very few or no motile spermatozoa in the ejaculate are suitable for HOS testing (Kızlay \& Altay, 2017; Peeraer, Nijs, Raick, \& Ombelet, 2004). A lower limit of 58\% vitality is accepted. This test represents a good choice when sperm staining methods are not an option, especially before ICSI (World Health Organization, 2010).
The opinions regarding the hypo-osmotic swelling test are divided with regard to IVF success. While Barratt et al. (1989) reported that this test has no predictive value for patients undergoing IVF, Jeyendran, Van der Ven, Perez-Pelaez, Crabo, and Zaneveld (1984) concluded the HOST can be used in addition to the standard semen analysis because of its accuracy and ability to predict the IVF ability of spermatozoa.

Additional diagnostic value of this test is based on the fact the HOST highly predicts sperm viability, a parameter that appears to be associated with increased DNA fragmentation index (DFI) as measured by SCSA and TUNEL assay (Stanger, Vo, Yovich, \& Almahbobi, 2010). The result of the HOST is correlated with sperm parameters such as concentration $\left(r^{2}=.2179, p<.05\right)$, total motile spermatozoa $\left(r^{2}=.7103, p<.0001\right)$, progressive motile count $\left(r^{2}=.6912, p<.0001\right)$ and normal sperm morphology $\left(r^{2}=.3401\right.$, $p<.001$; Stanger et al., 2010). Couples undergoing IUI with a HOST score $<50 \%$ had lower pregnancy $(p<.05)$ and higher miscarriage rates $(p<.005)$ compared to those with HOST scores equal or more than 50\% (Tartagni et al., 2002). The HOST score was significantly lower $(p<.0001)$ in sperm specimens with anti-sperm antibodies compared to sperm specimens from normozoospermic men. Hence, the reduced fertility during ART of infertile men with anti-sperm antibodies could be due to poor membrane integrity, which is a reflection of cellular viability (Rossato, Galeazzi, Ferigo, \& Foresta, 2004).

\subsection{2 | Sperm mitochondrial membrane potential}

Mitochondrial function, mainly the mitochondrial membrane potential (MMP), can be assessed using both fluorescence microscopy and flow cytometry coupled with fluorescent dyes (Moraes \& Meyers, 2018). The principle of the assay is that MMP is correlated with the fluorescence colour and intensity (Perry, Norman, Barbieri, Brown, \& Gelbard, 2011). In order to evaluate the MMP in human spermatozoa, JC-1 and TMRM (tetramethylrhodamine methyl ester perchlorate) are the most commonly used fluorescent dyes (Moraes \& Meyers, 2018). Since JC-1 gives rather unreliable results (García-Macías et al., 2005; Uribe et al., 2017), TMRM is preferred to be used for human spermatozoa (Uribe et al., 2017). TMRM is a simple, time-effective method, easy to set in laboratories equipped with flow cytometry technology, and can accurately detect changes in $\Delta \Psi \mathrm{m}$ with efficiency comparable to JC-1 without its limitations (Uribe et al., 2017). Using this technique, the results obtained were comparable with semen parameters (Uribe et al., 2017).

The TMRM technique for MMP measurement is simple, time-effective and easy to perform in a clinical laboratory (Uribe et al., 2017). It was shown that this test can discriminate between normal and low-quality semen samples $(p<.0001$; Uribe et al., 2017), and is associated with sperm parameters such as progressive motility, viability, normal morphology, sperm count and seminal volume ( $p<.003$ for all parameters; Espinoza, Schulz, Sánchez, \& Villegas, 2009). This test also discriminates between astheno- and oligoasthenozoospermic patients ( $p=.003$ ), thus providing important information regarding the mitochondrial function in semen specimens (Zou, Liu, Ding, \& Xing, 2010). Consequently, 
this test can be used to complement the routine semen analysis (Espinoza et al., 2009).

Determination of the rate of mitochondrial oxygen consumption is a more direct approach to measure the mitochondrial bioenergetics involved in sperm motility and can be determined by means of polarography. This assay of oxygen consumption has been introduced by Moraes and Meyers (2018). However, this technique needs a closed system and has low throughput, making it irrelevant for clinical practice (Moraes \& Meyers, 2018).

\subsection{3 | Hyaluronan binding assay}

Only mature spermatozoa with normal morphology, minimal DNA fragmentation, normal chromatin condensation, lesser chromosomal aneuploidies and intact acrosomes bind to hyaluronic acid, a compound in the cumulus matrix that surrounds human oocytes (Huszar et al., 2003; Myles \& Primakoff, 1997). Bound spermatozoa have completed the spermiogenetic processes and are not acrosome-reacted (Huszar et al., 2003; Oehninger et al., 2014). The hyaluronan binding assay (HBA) assesses sperm maturity and viability (Huszar et al., 2003; Oehninger et al., 2014). There are two methods for selecting spermatozoa with high affinity to hyaluronic acid: the hyaluronic acid (HA) culture dish (PICSI, physiological intracytoplasmic sperm injection) and a viscous medium containing HA (Sperm Slow ${ }^{\circledR}$; Kızılay \& Altay, 2017).

Liu et al. (2014) reported a higher acrosome integrity and MMP in motile spermatozoa bound to hyaluronic acid (HA) compared with spermatozoa in the initial semen specimen $(p<.01)$. Furthermore, the percentage of spermatozoa bound to HA was weakly $(r=.195-$ $0.268, p<.05)$ positively correlated with AR, normal morphology and negatively correlated with DNA fragmentation $(r=-.308, p<.01)$ and excessive residual cytoplasm ( $r=-.218, p<.05$; Liu et al., 2014). Tarozzi et al. (2009) found that spermatozoa bound to hyaluronan and sperm morphology are correlated both before and after density gradient centrifugation ( $r=.458$ and $r=.358$, respectively). This test discriminates between DNA fragmentation within the overall sperm population and that in sperm bound to hyaluronan $(p=.029$; Tarozzi et al., 2009). A contradictory result was shown in a study conducted by Nijs et al. (2010) in which the authors conclude that this test is not able to discriminate between patients with high, low and failed fertilisation rates. Moreover, the hyaluronan binding assay was not in relation with other reproductive outcomes such as fertilisation rate, implantation and miscarriages (Tarozzi et al., 2009).

\subsection{4 | Anti-sperm antibodies test}

Anti-sperm antibodies (ASA) are one of the causes of male infertility and are found in about $9.5 \%$ of men with abnormal semen samples (Munuce, Berta, Pauluzzi, \& Caille, 2000). The ASA test is recommended to patients with asthenozoospermia, with disrupted blood-testis barrier, or when sperm agglutination can be observed during a routine semen analysis (Snow-Lisy \& Sabanegh, 2013). One of the causes for sperm agglutination is the presence of ASA (Berger, Smith-Harrison, \& Sandlow, 2019). ASA in the serum and seminal plasma can lead to male infertility by interfering with sperm motility and sperm-oocyte binding (Agarwal \& Said, 2009; Chiu \& Chamley, 2004) and incapacity of penetrating the cervical mucus (De Almeida, Soumah, \& Jouannet, 1986).

Numerous tests have been developed to identify antibodies on the sperm surface, such as immunobead assays (IBT, Immunobead Test), MAR (mixed antiglobulin reaction) test, ELISA, tray agglutination tests (TAT), sperm immobilisation assay tests, flow cytometry and radiolabelled agglutinin assays (Mazumdar \& Levine, 1998). However, the WHO only recommends the MAR and IBT tests for diagnostic purpose as only these tests correlate with immunological infertility (Agarwal \& Said, 2009; World Health Organization, 2010). The preferred commercially available kit for the MAR test is the SpermMAR kit. The formation of agglutination between motile sperm and latex particles is an indication of IgA ASA present on the sperm surface (Agarwal \& Said, 2009).

The IBT (immunobead binding test) test for ASA is specific and sensitive. However, it is an expensive method to perform as it is time-consuming and requires a highly skilled operator, and it is difficult to interpret the results (Mazumdar \& Levine, 1998). Similarly, the MAR test is a fast specific assay, but needs a highly skilled operator. Furthermore, the sensitivity of this test remains unknown and the costs are very high (Mazumdar \& Levine, 1998). The SpermMAR test identified ASA in about $13 \%$ of infertile men (Sinisi et al., 1993). A systematic review and meta-analysis reported that the presence of ASA is negatively correlated with sperm concentration (Cui, Han et al., 2015) and motility (Cui, Han et al., 2015; Sinisi et al., 1993). Further, the presence of ASA increased the time of semen liquefaction (Cui, Han et al., 2015).

\section{4 | FACTORS THAT CAN AFFECT SPERM QUALITY}

Sperm quality is affected by a series of factors such as lifestyle, health or environmental factors. Lifestyle factors such as cigarette smoking, alcohol and caffeine consumption, use of recreational drugs or poor diet have been strongly correlated with the decrease of semen parameters (Durairajanayagam, 2018). On the other hand, health conditions such as obesity, psychological and genital heat stress, advanced paternal age and sleep disturbances can also cause sperm quality impairment (Durairajanayagam, 2018). Similarly, environmental factors such as pesticides, phthalates, air pollution and mobile phones affect the quality of the spermatozoa by decreasing the sperm parameters (Jurewicz, Hanke, Radwan, \& Bonde, 2009). Additionally, geographical or regional factors have also been associated with the quality of the semen (Elbardisi et al., 2018).

\section{1 | Oxidative stress}

Oxidative stress is caused by the imbalance between ROS and antioxidants. ROS are a group of radical and non-radical derivatives of oxygen 


\section{Primary Pathologies of Male Reproductive System}

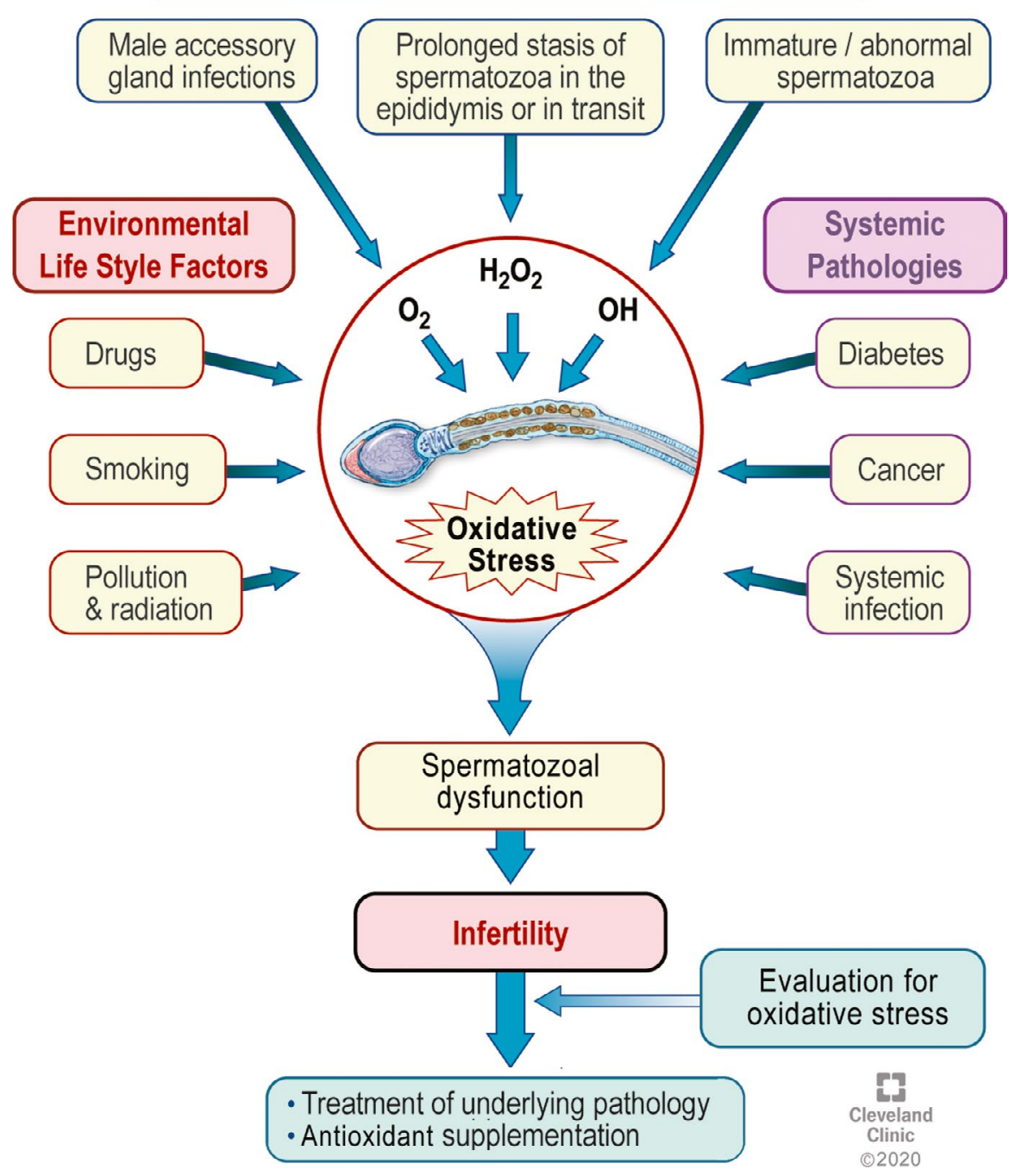

FIGURE 2 Causes of oxidative stress in human spermatozoa (Reprinted with permission, Cleveland Clinic Center for Medical Art \& Photography (C2011-2020. All Rights Reserved) (e.g. superoxide anion, hydrogen peroxide, hypochlorite, hydroxyl radical) that are normally produced in the body. Physiological ROS levels play an important role during sperm maturation, more precisely during capacitation, hyperactivation, acrosome reaction and oocyte fusion (Agarwal \& Bui, 2017; de Lamirande, Leduc, Iwasaki, Hassouna, \& Gagnon, 1995; Du Plessis, Agarwal, Halabi, \& Tvrda, 2015). However, OS occurs when ROS outweigh the seminal plasma antioxidant capacity (Ayaz et al., 2015). This imbalance leads to lipid peroxidation and DNA damage, and induces apoptosis (Agarwal \& Bui, 2017; Aitken, 2017).

\subsubsection{Sources of ROS in semen}

The sources of ROS in semen can be classified as lifestyle factors, environmental factors and health factors. Lifestyle factors increase the levels of ROS include smoking, alcohol and recreational drug abuse. Pesticides, air pollutants, electromagnetic and ionising radiation are environmental factors that increase ROS production. Health factors such as stress, strenuous exercise, chemotherapy, urogenital infections, varicocele, spinal cord injury, diabetes and prostatitis can also increase the production of ROS (Agarwal \& Bui, 2017; Aitken, Gibb, Baker, Drevet, \& Gharagozloo, 2016; Ayaz et al., 2015; de Lamirande et al., 1995; Sabeti, Pourmasumi, Rahiminia, Akyash, \& Talebi, 2016). Nevertheless, leukocytes and immature spermatozoa are the major sources of ROS in semen. While leukocytes are an external source and predominantly affect the sperm plasma membrane, immature and abnormal spermatozoa (internal source) also affect the sperm DNA (Figure 2; Agarwal \& Bui, 2017; Aitken \& Baker, 1995).

\subsection{2 | Impact of pro-oxidant/antioxidant imbalance on sperm quality}

Under physiological conditions, ROS support normal function of spermatozoa (Agarwal \& Bui, 2017; Du Plessis et al., 2015). However, the imbalance between pro-oxidants or ROS and antioxidants or reductants results in OS, which can cause lipid peroxidation, DNA damage and apoptosis. As a consequence, more 
ROS are produced and can trigger a vicious cycle of OS (Agarwal \& Bui, 2017; Aitken, 2017). High concentrations of ROS affect the sperm plasma membrane, which is extraordinarily rich in polyunsaturated fatty acids (PUFA). As a consequence, these PUFA are highly susceptible to oxidation, a process that leads to lipid peroxidation of the membrane lipids. It has been reported that extrinsic ROS affect sperm motility (Aitken, 2017), while high intracellular levels of OS were correlated with increased levels of DNA fragmentation and low sperm motility (Agarwal, Sharma, et al., 2014; Mahfouz et al., 2010; Sharma et al., 2010). Further, OS has been reported to exert harmful effects on other sperm parameters such as ejaculate volume, concentration, morphology and viability (Agarwal, Mulgund, Sharma, \& Sabanegh, 2014; Agarwal, Sharma, et al., 2014).

\subsection{3 | Measurement of seminal ROS levels}

Measuring ROS is the most commonly used method for OS assessment. Currently, available assays for the measurement of seminal ROS levels include chemiluminescence, flow cytometry, thiobarbituric acid reactive substances, nitroblue tetrazolium and oxidationreduction potential.

\section{Chemiluminescence}

Chemiluminescence is the most commonly used method for the detection of ROS based on the reaction of extra- and intracellular ROS with a luminescent probe, mostly luminol or lucigenin, at neutral $\mathrm{pH}$. It is a direct and sensitive method. While lucigenin is specific for extracellular superoxide, luminol detects all ROS, extracellular and intracellular (Aitken, Buckingham, \& West, 1992). When these chemiluminescent compounds combine with free radicals, a light signal is generated, which can be detected with a luminometer that converts the light signal to an electrical signal. The levels of ROS are measured as relative light units (RLU).

Using the chemiluminescence technique, Agarwal, Ahmad, and Sharma (2015) reported that a cut-off of $102.2 \mathrm{RLU} / \mathrm{s} / 10^{6}$ spermatozoa for seminal ROS was able to differentiate between fertile and infertile men with good sensitivity (76.4\%) and specificity (53.3\%). The studies also revealed that ROS are negatively correlated with the ejaculate volume $(r=-.111 ; p=.046)$, sperm motility $(r=-.265$; $p<.001)$ and concentration $(r=-.373 ; p<.001$; Agarwal, Sharma, et al., 2014). Further, a meta-analysis concluded that ROS levels are in weak negative correlation with the fertilisation rate after IVF (estimated overall correlation -0.374). Thus, tools measuring ROS may be useful to predict the IVF outcome (Agarwal, Allamaneni, Nallella, George, \& Mascha, 2005). However, the disadvantages of this technique are that ROS cannot be measured in frozen samples, azoospermic and low-volume ejaculate specimens (Sharma et al., 2019). Overall, chemiluminescence is a reliable, reproducible and accurate technique with a diagnostic value in the evaluation of male infertility (Agarwal, Sharma, et al., 2014; Vessey, Perez-Miranda, Macfarquhar, Agarwal, \& Homa, 2014) and is recommended for patients with idiopathic or unexplained infertility (Agarwal, Cho, \& Sharma, 2018).

\section{Fluorescence: flow cytometry}

Flow cytometry is used to distinguish a specific sperm population after adjusting the cell suspension to a density of $10^{5}-10^{7}$ cells $/ \mathrm{ml}$ (Gosálvez, Tvrda, \& Agarwal, 2017). Sperm cells are labelled with a fluorescent dye, which is excited by a laser, and the emitted light is then detected. In addition, the light scatter signals (forward and sideward) are measured (Mahfouz, Sharma, Lackner, Aziz, \& Agarwal, 2009). This technique allows the measurement of 10,000 events (Gosálvez et al., 2017), and both specific and non-specific fluorescent probes can be used (Dolník, Mudroňová, Pošivák, Lazar, \& Mudroň, 2019). Specific fluorescent probes recognise a particular type of ROS. For instance, while dihydroethidium specifically detects intracellular superoxide (Mahfouz, Sharma, Lackner, et al., 2009), 2',7'-dichlorofluorescein diacetate generally detects different types of intracellular ROS (Gosálvez et al., 2017). Oxidation of these probes changes their properties from non-fluorescent to fluorescent (Martínez-Pastor et al., 2010). The level of fluorescence is determined by the extent of the OS/the concentration of ROS available (Dolník et al., 2019; Hossain et al., 2011).

When analysing intracellular ROS, flow cytometry is considered a more specific, accurate and sensitive method compared to chemiluminescence, as it focuses specifically on male germ cells (Gosálvez et al., 2017). On the other hand, chemiluminescent determination of intracellular ROS levels in spermatozoa gave negative results (Mahfouz, Sharma, Lackner, et al., 2009). Flow cytometry requires low sperm count, being a good test option for patients with oligozoospermia (Mahfouz, Sharma, Lackner, et al., 2009). However, the disadvantages of this technique are the expensive and sophisticated equipment required to perform it (Gosálvez et al., 2017).

\section{Thiobarbituric acid reactive substances}

Malondialdehyde (MDA) is a by-product of lipid peroxidation. Thiobarbituric acid (TBA) reactive substances (TBARS) measure the damage produced after lipid peroxidation by accessing MDA with spectrophotometry or fluorometry (Agarwal, Cho, et al., 2018; Agarwal, Henkel, Sharma, Tadros, \& Sabanegh, 2018). The concentration of TBARS is determined as the coefficient of molar absorptivity of the product (Gosálvez et al., 2017). As the MDA levels in seminal plasma are 5- to 10-fold higher than in spermatozoa, seminal MDA can be easily measured by spectrophotometry (Agarwal \& Majzoub, 2017; Tavilani, Doosti, \& Saeidi, 2005). Since the TBARS assay is a relatively simple test, albeit with low specificity (Agarwal, Cho, et al., 2018), it is the most widely used direct technique for assessing sperm membrane oxidation (Agarwal, Virk, Ong, \& Plessis, 2014).

Lipid peroxidation evaluated by TBARS was strongly correlated with sperm concentration $(r=-.736, p=.000)$ and moderately correlated with total sperm count $(r=-.509, p=.026)$, semen volume ( $r=.479, p=.038$; Patricio et al., 2016) and with progressive motile spermatozoa $(r=-.41, p<.05$; Zarghami \& 
Khosrowbeygi, 2004). Moreover, seminal plasma MDA levels were significantly higher in infertile men than in fertile controls $(p<.05$; Nakamura et al., 2002).

\section{Nitroblue tetrazolium}

The nitroblue tetrazolium (NBT) test is a direct measurement for ROS produced by spermatozoa and leukocytes. This is an inexpensive and sensitive method that uses NBT, a yellow-soluble nitrosubstituted aromatic tetrazolium compound. NBT is reduced by cellular superoxide ions and forms a formazan, which is a compound coloured blue-black that can be monitored spectrophotometrically. This test allows identification of ROS of cellular origin in the seminal ejaculate (Agarwal, Cho, et al., 2018; Agarwal, Henkel, et al., 2018; Esfandiari, Sharma, Saleh, Thomas, \& Agarwal, 2003). The NBT positive response in leukocytes in the whole ejaculate $(r=.59, p=.0006)$ and leukocytes $(r=.7, p<.0001)$ strongly correlates with the result of chemiluminescent assay (Esfandiari et al., 2003). The NBT test gives valuable information about the contribution of leukocytes and defective spermatozoa to the generation of ROS (Esfandiari et al., 2003). This test is a good preliminary tool for patients with suspected high ROS levels (Agarwal, Cho, et al., 2018; Agarwal, Henkel, et al., 2018).

\subsection{4 | Measurement of total antioxidant capacity}

The currently available assay for antioxidant measurements is the total antioxidant capacity (TAC) assay (Mahfouz, Sharma, Sharma, Sabanegh, \& Agarwal, 2009). This technique measures the levels of enzymatic or non-enzymatic antioxidants in semen samples by using a colorimetric or spectrophotometric assay. The colorimetric assay is the most widely used and employs 2,20-azino-di-[3-ethylbenzthiazoline sulfonate] (ABTS) as specific reagent (Agarwal, Cho, et al., 2018; Agarwal, Henkel, et al., 2018). It tests the ability of the seminal plasma antioxidants to inhibit the oxidation of ABTS to ABTS ${ }^{+}$, which is compared to that of Trolox (6-hydroxy-2,5,7,8-tetramethylchroman-2-carboxylic acid). The final result is reported as micromoles $(\mu \mathrm{M})$ of Trolox equivalent (Roychoudhury, Sharma, Sikka, \& Agarwal, 2016).

The TAC method was able to distinguish the prevalence of OS in infertile patients compared with healthy men at a cut-off of $1,947 \mu \mathrm{M}$ in seminal plasma (Roychoudhury et al., 2016). TAC is a simple, accurate and reliable tool for the diagnosis and management of male infertility (Said et al., 2003). However, the TAC results should be assessed in combination with the amount of seminal ROS to have an overview of the impact of OS on semen quality and sperm function (Gupta, Caraballo, \& Agarwal, 2019).

\subsection{5 | Oxidation-reduction potential}

The standard assays to determine seminal OS (chemiluminescence, flow cytometry, TBARS and NBT) only quantify ROS levels, which are only reflecting the OS side of the redox homeostasis. On the other hand, antioxidants, the counterparts of ROS, are determined using the TAC assay. In order to cover both sides, the effects of oxidants and reductants, and the oxidation-reduction potential (ORP), a direct method to determine OS that includes both ROS and antioxidant measurement can be used. It indicates the redox state, that is the balance between oxidants and reductants in a given semen sample (Agarwal \& Bui, 2017). Further, this is a simple and fast screening tool for the overall oxidative status of semen. ORP is measured using the MiOXSYS (male infertility oxidative system), which is a method based on a galvanostatic technique. It indicates the ORP that represents the actual redox balance (Agarwal et al., 2019) in milli Volts (mV), a variable that is then normalised to the sperm concentration. The latter is reported as $\mathrm{mV} / 10^{6} \mathrm{sperm} / \mathrm{ml}$. A clinical cut-off of $1.34 \mathrm{mV} / 10^{6} \mathrm{sperm} / \mathrm{ml}$ has been established (Agarwal et al., 2019).

The multicentre study that analysed 2,092 patients in nine countries reported that at a cut-off value of $1.34 \mathrm{mV} / 10^{6}$ sperm/ $\mathrm{ml}$, the ORP test was able to differentiate specimens with abnormal semen parameters (Agarwal et al., 2019). The ORP value as determined by the MiOXSYS is statistically significantly higher in infertile patients compared with healthy men $(p<.001$; Agarwal $\&$ Bui, 2017). A positive correlation between ORP and sperm DNA fragmentation (SDF) was reported $(r=.22, p<.001)$ in infertile patients (Majzoub et al., 2018). Hence, the ORP test is a reliable marker of semen quality and OS (Agarwal, Henkel, et al., 2018; Arafa et al., 2018) and a helpful method when selecting patients for OS treatment and for monitoring the treatment response (Agarwal, Cho, et al., 2018; Agarwal, Henkel, et al., 2018). Further, it may help in cases of couples with idiopathic male infertility caused by OS and couples with recurrent pregnancy loss (Agarwal et al., 2019) because OS may play a key pathologic role in these cases and the results could lead to better management of these couples.

\section{2 | Sperm DNA damage}

During spermatogenesis, undifferentiated stem cells proliferate and differentiate in spermatozoa. This process consists of spermatogonial proliferation, meiosis and spermiogenesis (Gunes, Al-Sadaan, \& Agarwal, 2015; Paoli, Pallotti, Lenzi, \& Lombardo, 2018). It is essential that the sperm DNA structure remains intact throughout the proliferation and differentiation steps so that the genetic information is correctly transferred to the next generation. One of the most common causes of male infertility is represented by SDF, a type of DNA damage (Ribeiro et al., 2017).

\subsection{1 | Sources of sperm DNA damage}

Sperm DNA damage can occur at the level of testicles, epididymis or after ejaculation (Lewis \& Aitken, 2005). A decrease in sperm DNA integrity can be caused by environmental conditions such as 
cigarette smoking (Le et al., 2019; Potts, Newbury, Smith, Notarianni, \& Jefferies, 1999), irradiation (Arnon, Meirow, Lewis-Roness, \& Ornoy, 2001), chemotherapy (Morris, 2002), alcohol consumption (Le et al., 2019) and environmental toxins (Zini \& Libman, 2006). Pathophysiologic conditions have also been associated with sperm DNA damage, and examples of such conditions are genital tract inflammation that result in leukocytospermia (Alvarez et al., 2002), varicocele (Saleh, Agarwal, Sharma, et al., 2003), cancer (Kobayashi et al., 2001), hormonal factors (Zini \& Libman, 2006), testicular hyperthermia and febrile illness (Evenson, Jost, Corzett, \& Balhorn, 2000; Zini \& Libman, 2006). Further, sperm cryopreservation (Lewis \& Aitken, 2005) and the age of the patient (Alshahrani et al., 2014; Le et al., 2019) are also associated with increased sperm DNA damage. The conditions mentioned above can lead to increased sperm DNA damage or chromatin abnormalities by three different mechanisms: ROS, abortive apoptosis and abnormalities in chromatin packaging (Schulte, Ohl, Sigman, \& Smith, 2010).

\subsubsection{Impact of sperm DNA damage on sperm quality}

DNA damage can occur as single- (ss) and double-strand (ds) DNA breaks, as well as alteration of bases (Singh \& Agarwal, 2011). Sperm DNA damage is a biomarker for male infertility with clinical value in diagnosis and prediction of conception (Lewis et al., 2013).

Several studies concluded that sperm DNA damage is associated with abnormalities in conventional semen parameters such as motility (Kvitko et al., 2012; Le et al., 2019; Sun, Jurisicova, \& Casper, 1997; Zini, Bielecki, Phang, \& Zenzes, 2001), morphology (Le et al., 2019; Sun et al., 1997) and concentration (Irvine et al., 2000; Sun et al., 1997; Zini et al., 2001). Zini et al. (2001) reported a significant statistical association between DNA denaturation, sperm motility and morphology ( $p<.0001$ and $p=.029$, respectively). Further, several studies reported that SDF was statistically associated with sperm concentration (Irvine et al., 2000; Sun et al., 1997; Zini et al., 2001), morphology (Le et al., 2019; Sun et al., 1997) and motility (Kvitko et al., 2012; Le et al., 2019; Sun et al., 1997; Zini et al., 2001). A systematic review and meta-analysis reported that patients with a low level of SDF had higher live birth rates compared to those with high SDF (Osman, Alsomait, Seshadri, El-Toukhy, \& Khalaf, 2015).

\subsection{3 | Measurement of sperm DNA damage}

A variety of techniques have been developed to assess the integrity of the genetic material of sperm cells, mainly the terminal deoxynucleotidyl transferase dUTP nick end labelling (TUNEL) assay, Comet assay, sperm chromatin dispersion (SCD) test, cytochemical tests such as acridine orange (AO), toluidine blue (TB) and chromomycin A3 (CMA3), and the Sperm Chromatin Structure Assay (SCSA $\left.{ }^{\circledR}\right)$. TUNEL and Comet assay under neutral $\mathrm{pH}$ conditions are direct assays for sperm DNA damage measurement. Direct tests measure sperm DNA strand breaks or abnormalities in the structure of the chromatin (Schulte et al., 2010). Indirect assays such as SCD and SCSA measure the breaks that already exist in DNA and the susceptibility of DNA to denaturation (Henkel, 2007).

Measuring SDF is challenging because there are numerous techniques that produce variable and inconsistent results. Thus, the predictive power and clinical implications vary markedly between different techniques (Ribeiro et al., 2017). Standardised protocols have only been published for the SCSA (Evenson, 2013), TUNEL (Ribeiro et al., 2017; Sharma, Ahmad, Esteves, \& Agarwal, 2016), SCD (Evenson, 2016; Gosálvez, López-Fernández, \& Fernández, 2013) and the Comet assay (Simon \& Carrell, 2013). SDF testing can be considered in patients with varicocele, unexplained infertility, IUI failure, recurrent pregnancy loss, IVF and/or ICSI failure, or when semen parameters are borderline but the patients present with modifiable lifestyle risk factors (Agarwal, Cho, Majzoub, \& Esteves, 2017).

\section{TUNEL assay}

The TUNEL assay is a direct test, which quantifies real sperm DNA damage (Figure 3; Henkel, Hoogendijk, Bouic, \& Kruger, 2010; Ribeiro et al., 2017). This method uses the enzyme TdT (DNA polymerase) that adds fluorescein-labelled deoxyribonucleotides (dUTP) in a non-preferential way to free single- and double-stranded 3 '-hydroxyl (OH) break ends (Sharma et al., 2016). With this technique, the incorporation of dUTP into DNA breaks is quantified as percentage of fluorescent spermatozoa (DFI). Both, flow cytometry and fluorescence microscopy can be used (Agarwal et al., 2017). However, the DFI obtained by cytometry and fluorescence microscopy cannot be directly compared with the results obtained from the TUNEL assay as both assays measure different aspects of sperm DNA damage (Henkel et al., 2010).

The TUNEL assay has been standardised by Sharma et al. (2016), and at a cut-off value of $16.8 \%$, the test showed high specificity (91.6\%). SDF was significantly higher in infertile patients compared with that in control men $(p<.001)$. While the controls had an upper limit of SDF that was equal to $19.6 \%$, infertile patients had an upper limit of SDF that was equal to $68.9 \%$ (Sharma et al., 2016). Sperm parameters such as morphology $(r=-.4423, p=.0026)$, motility $(r=.4818, p=.0008)$ and progressive motility ( $r=.4545, p=.0017)$ were correlated with the DFI (Henkel et al., 2003). Furthermore, high correlation between DFI and sperm parameters was identified, such as total sperm count, concentration, motility and normal sperm morphology in patients undergoing ICSI (Borini et al., 2006). The association of DFI with pregnancy outcomes and fertilisation is uncertain as studies report different conclusions. Some researchers mention that DNA fragmentation measured by the TUNEL assay is a prognostic indicator of pregnancy (Benchaib et al., 2007; Borini et al., 2006), fertilisation (Benchaib et al., 2007) and pregnancy loss (Borini et al., 2006), while others report no association (Henkel et al., 2003). However, a meta-analysis published by Cui, Han, et al. (2015) and Cui, Zheng, et al. (2015) concluded that the TUNEL assay achieved higher 


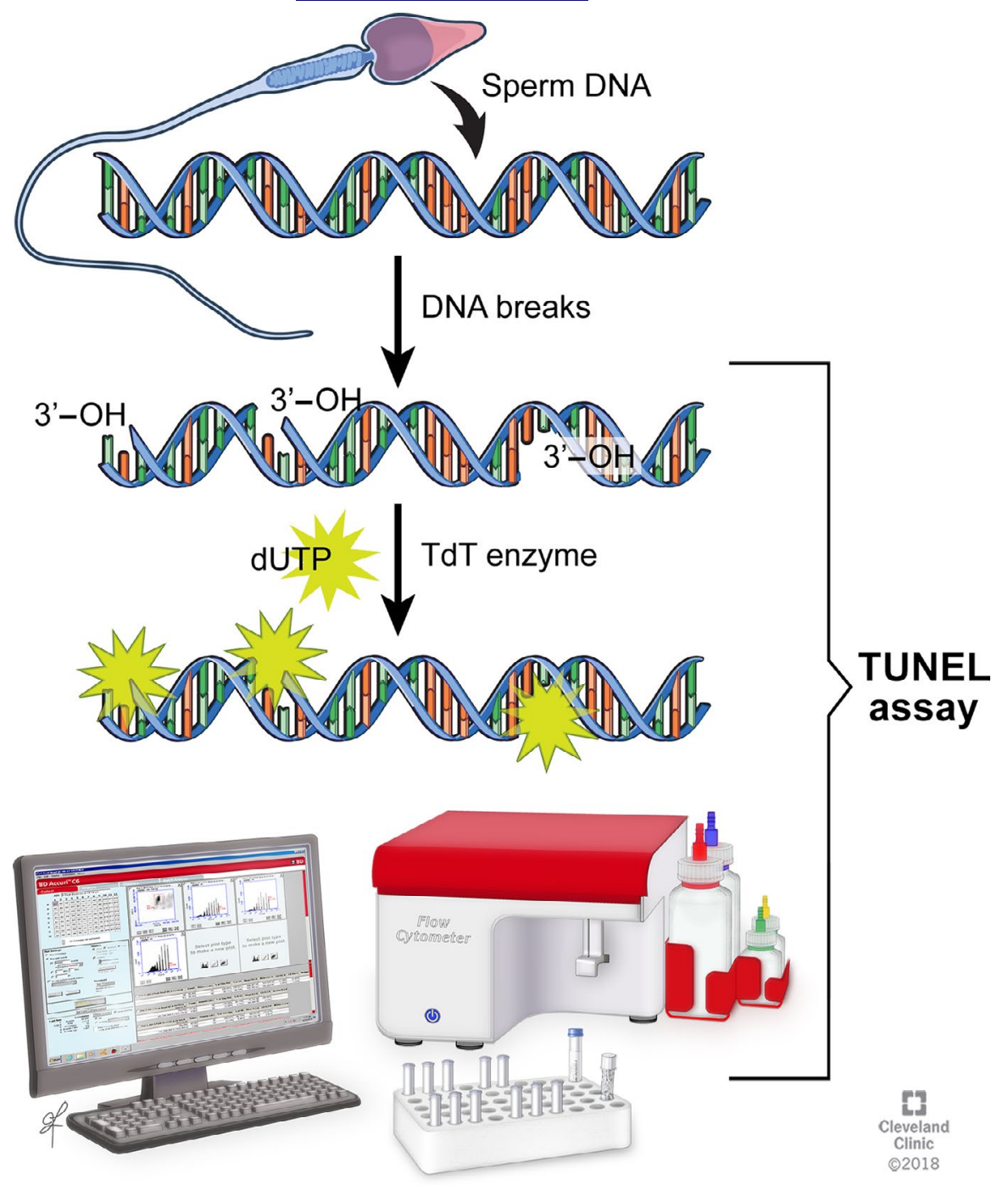

FIGURE 3 TUNEL assay for the assessment of sperm DNA fragmentation (Reprinted with permission, Cleveland Clinic Center for Medical Art \& Photography (C2011-2020. All Rights Reserved) accuracy regarding the diagnostic value for male infertility compared to SCD and Comet assay.

\section{Comet assay}

The Comet assay or single-cell gel electrophoresis is a direct test that detects sperm ssDNA and dsDNA breaks at the single-cell level (Enciso, Sarasa, Agarwal, Fernández, \& Gosálvez, 2009). This technique is based on the fact that DNA fragments migrate in an electric field according to their weight from the anode to the cathode resulting in the formation of a comet tail emerging from the nucleoid (Enciso et al., 2009). During agarose gel electrophoresis, high-molecular weight (intact) DNA fragments migrate very little or do not migrate at all and remain at the 'head of comet'. In contrast, low-molecular weight (broken) DNA fragments migrate in a manner that represents the image of a comet's tail (Simon \& Carrell, 2013). The decondensed sperm DNA (using neutral or alkaline denaturing conditions) is stained with a fluorescent DNA-binding dye (Evenson, 2016). The level of DNA fragmentation is visualised using an imaging software, and the comet tail length and fluorescence intensity are measured (Schulte et al., 2010). In the Comet assay under neutral $\mathrm{pH}$ conditions for lysis and electrophoresis, the identification of dsDNA breaks is possible. In the alkaline Comet assay, the DNA is decondensed and this condition allows the identification of both ssDNA and dsDNA breaks without distinction (Enciso et al., 2009; Singh, McCoy, Tice, \& Schneider, 1988).

The Comet assay is a sensitive and inexpensive technique, which allows assessment of DNA damage in single spermatozoa rather than an overall percentage of DNA fragmentation in the whole semen sample (Lewis et al., 2013). This assay requires a small number of cells for analysis, and thus, DNA fragmentation can even be determined in samples with low sperm counts. The DNA integrity is evaluated as the frequency of sperm cells containing fragmented DNA (Enciso et al., 2009). Analysing between 50 and 500 spermatozoa is enough to have clear view of the DNA damage status of the whole sperm specimen with a coefficient of variation lower than $4 \%$ (Lewis et al., 2013). This technique detects protamine- and histone-bound chromatin breaks equally (Lewis et al., 2013).

A weak correlation between DNA fragmentation measured by the neutral Comet assay and semen parameters was reported (Trisini, Singh, Duty, \& Hauser, 2004). In addition, the neutral Comet assay was not able to distinguish between fertile and infertile men, presenting no 
diagnostic value (Ribas-Maynou et al., 2013). In two different studies, Simon, Lutton, McManus, and Lewis (2011) and Simon et al. (2013) recommend the alkaline Comet assay as a diagnostic tool for male infertility and IVF outcomes. Low fertilisation and pregnancy rates, and poor embryo quality were associated with increased levels of DNA fragmentation in spermatozoa (Simon, Castillo, Oliva, \& Lewis, 2011). The alkaline Comet assay best predicted male infertility followed by TUNEL, SCD and SCSA (Ribas-Maynou et al., 2013). The disadvantages of the alkaline Comet assay are that it is a laborious assay with inter-laboratory variation, which makes it a less desirable diagnostic test (Simon \& Carrell, 2013).

\section{Sperm chromatin dispersion test}

Sperm DNA fragmentation is linked with the level of nuclear condensation as spermatozoa with fragmented DNA are more susceptible to DNA denaturation (Agarwal et al., 2017). The SCD test or Halo test is an indirect assay based on fluorescence microscopic evaluation. This technique is based on the fact that after DNA denaturation and nuclear protein removal, sperm cells with intact DNA form a characteristic halo of dispersed DNA loops when loaded on an agarose gel. Spermatozoa with fragmented DNA will have nondispersed chromatin (small halos). It mostly measures the absence of damaged DNA in spermatozoa. ssDNA damage is proportional with the amount of non-dispersed chromatin (Agarwal et al., 2017).

To date, statistically significant correlations have been identified between SDF assessed by the Halosperm test and sperm parameters such as motility, morphology and concentration (Velez de la Calle et al., 2008). It was reported that the rate of SDF is directly proportional with zygotes displaying asynchrony between the nucleolar precursor bodies of zygote pronuclei ( $p=.001$; Muriel et al., 2006). In addition, SDF in testicular spermatozoa tested by the SCD assay was higher in patients with non-obstructive azoospermia than in testicular spermatozoa of patients with obstructive azoospermia. However, in this study, besides the group of patients with non-obstructive azoospermia and patients with obstructive azoospermia, no additional groups of fertile men were included to compare the results (Meseguer et al., 2009). DFI measured by the SCD assay at the cut-off of $26.1 \%$ has a high diagnostic value in differentiating infertile from fertile men (Wiweko \& Utami, 2017). At the cut-off value of $18 \%$ of SDF, this technique is a good predictor of fertilisation (Velez de la Calle et al., 2008). A value more that $25.5 \%$ of DFI is associated with higher IVF failure rates (López, Lafuente, Checa, Carreras, \& Brassesco, 2013). However, no significant correlation was identified between SDF measured by the SCD test and clinical pregnancies or births for couples undergoing IVF and ICSI (Velez de la Calle et al., 2008). A meta-analysis investigating the impact of SDF on clinical outcome parameters after assisted reproduction indicated that SDF has only limited predictive capacity (Cissen et al., 2016). Specifically, the SCD and SCSA were shown to have poor predictive power, while the predictive capacity of the TUNEL and Comet assays was with areas under the curve (AUC) of 0.71 and 0.73 , respectively, indicating fair predictive capacity. Overall, hierarchical summary receiver operating characteristic (HSROC) plots and Forest plots indicated a high variability of specificity and sensitivity of SDF to predict pregnancy.

Cytochemical tests (acridine orange, toluidine blue and chromomycin A3)

The acridine orange $(\mathrm{AO})$ test uses acridine orange, a dye with metachromatic properties, to measure DNA integrity by differentiating between normal dsDNA from denatured ssDNA. Depending on the type of DNA, AO intercalates with and emits a different colour, green for dsDNA and red for ssDNA. Fluorescence microscopy is used to determine the extent of DNA denaturation (Agarwal et al., 2017; Ajina et al., 2017; Schulte et al., 2010).

Red-fluorescing sperm cells as identified by the AO test were significantly correlated with sperm parameters such as normal morphology and viability (Ajina et al., 2017). The cut-off of $58 \%$ of cells that turned red was considered as an indicator of abnormal chromatin status (Cebesoy, Aydos, \& Unlu, 2006). However, the AO test is not very efficient and is also limited in terms of the fluorescence duration, staining heterogeneity, being prone to visual errors and a probability of appearance of artefacts (Pourmasumi et al., 2017).

The toluidine blue (TB) test is based on the fact that spermatozoa with abnormal chromatin packaging and impaired DNA present with phosphate residues that are prone to bind to basic (cationic) dyes such as toluidine blue. Spermatozoa with tightly bound DNA are lighter stained (or colourless) and have few TB binding sites. Spermatozoa with low DNA integrity are dark (blue) stained as they have high TB binding capacity (Ajina et al., 2017). This method is an inexpensive, light microscopy-based technique. Therefore, only a relatively small number of sperm cells can be analysed (Schulte et al., 2010; Tsarev et al., 2009).

Ajina et al. (2017) reported significant correlations between spermatozoa with low DNA integrity (blue stained) in the toluidine blue test and normal morphology, motility and viability. The proportion of dark TB-stained spermatozoa $(p<.001)$ and light TB-stained spermatozoa $(p<.001)$ were statistically different between infertile and fertile men (Tsarev et al., 2009). This test could predict male infertility at the cut-off of $45 \%$ for dark TB-stained cells (Tsarev et al., 2009). Schlegel and Paduch stated that the TB test can better measure the interactions between DNA and proteins than did the SCSA (Schlegel \& Paduch, 2005). The results of the TB test correlate well with those of the AO test (Ajina et al., 2017; Erenpreisa et al., 2003; Schlegel \& Paduch, 2005). The TB test may be clinically applied in future as a complementary test to standard semen analysis for the assessment of the male fertility potential.

Chromomycin A3 (CMA3) staining is an indirect test that analyses the chromatin condensation, instead of DNA integrity. It is used for determination of protamine deficiency in the chromatin structure. CMA3 is an antitumor agent, guanine-cytosine specific fluorochrome, which competes with protamines bound to DNA. Spermatozoa with histone-protamine displacement deficiencies are CMA3-positive cells and are identified in bright yellow colour using a fluorescent microscope (Nijs et al., 2009; Pourmasumi et al., 2017). 
The percentage of CMA3-positive sperm cells assessed by CMA3 was significantly associated with sperm count (Iranpour, Nasr-Esfahani, Valojerdi, \& Taki Al-Taraihi, 2000; Lolis et al., 1996), concentration (Nijs et al., 2009), motility (Iranpour et al., 2000) and morphological anomalies (Iranpour et al., 2000; Lolis et al., 1996). Sperm specimens with a percentage higher than 60\% of CMA3positive cells had high levels of round cells (Lolis et al., 1996). Furthermore, spermatozoa with low staining capacity tend to present higher fertilisation rates. Conversely, sperm specimens with a percentage $>30 \%$ of CMA3-positive cells had lower fertilisation rates (Sakkas et al., 1998).

\section{Sperm chromatin structure assay}

The sperm chromatin structure assay $\left(\mathrm{SCSA}^{\circledR}\right)$ is an indirect test based on flow cytometry that analyses sperm chromatin integrity. This assay is used to determine the susceptibility of sperm DNA following denaturation induced by acids or heat which is resulting in ssDNA breaks (Henkel et al., 2010). The sample is stained with AO, which binds to DNA giving the red fluorescence colour to broken DNA, and green colour to unbroken DNA strands. The SCSA is considered the gold standard among the tests available for SDF testing (Ribeiro et al., 2017). This technique is a simple, reproducible, well-established methodology with established clinical thresholds, which makes it a good assay with diagnostic value in fertility clinics (Evenson, Kasperson, \& Wixon, 2007). The results are expressed as SDF index (\%) and high DNA stainable (HDS) cell fractions (\%).

The SCSA can differentiate fertile donors from patients with idiopathic and male factor infertility (Saleh, Agarwal, Nada, et al., 2003). In addition, the SCSA is a good predictor of sperm quality (Wang et al., 2017) as the DFI was inversely proportional to semen parameters $(p<.002)$ such as concentration, motility and morphology by WHO or strict criteria (Saleh, Agarwal, Nada, et al., 2003). In addition, the SCSA value was inversely correlated with sperm motility in asthenozoospermic patients $(p=.001$; Moradian Fard et al., 2019).

The DFI was higher in infertile patients who did not obtain a pregnancy with ART compared to those who were able to obtain a pregnancy using ART (Saleh, Agarwal, Nada, et al., 2003). It was reported that when the DFI assessed by SCSA exceeds the threshold value of $30 \%$, ICSI should be indicated in these couples (Bungum et al., 2007). Further, the SCSA alone can be used as a predictive tool in couples with recurrent spontaneous abortions as the DFI was significantly higher in these couples compared to the controls at a cut-off value of $13.59 \%$ (Yuan et al., 2019). The fertilisation rate was negatively correlated with DFI assessed by SCSA (Saleh, Agarwal, Nada, et al., 2003). Two studies have reported that the value given by this test may (Saleh, Agarwal, Nada, et al., 2003) or may not (Green et al., 2019) be associated with embryological outcomes. In addition, the value given by SCSA was not associated with clinical outcomes (Green et al., 2019). Boe-Hansen, Ersbøll, and Christensen (2005) concluded that the differences in results obtained by SCSA may occur based on the laboratory technician conducting the analysis, the day and the time of the day.

\section{5 | CONCLUSION}

Considering the low predictive value of standard semen analysis in predicting pregnancy outcomes, sperm functional tests are needed in the advanced workup of the infertile couple. Sperm function tests can be helpful to guide the clinician to choose the best treatment option for infertile couples. Several advanced semen analysis tests are currently available, and their clinical relevance has been extensively studied. These tests include specific sperm function tests including SDF as well as tests that measure ROS, antioxidants and ORP. Sperm function tests can assess the important characteristics of spermatozoa and predict the fertilisation and pregnancy outcomes of an infertile couple. It has been concluded that the most powerful test to assess the OS state is ORP. Although the majority of studies indicates a significant relationship between SDF and the outcome of assisted reproduction, other studies could not show this relationship. Therefore, assays aiming to test the function of the spermatozoa and measurement of DNA damage and OS should be better standardised, so they can be incorporated into the WHO guidelines.

\section{6 | TAKE HOME MESSAGE}

1. Advanced sperm testing can help in better predicting pregnancy in couples trying to conceive naturally or undergoing ART.

2. Standardized methodologies of advanced tests are needed in order to increase their diagnostic value in the evaluation of male infertility.

\section{ORCID}

Cătălina Barbăroșie iD https://orcid.org/0000-0002-2854-9834

Ashok Agarwal iD https://orcid.org/0000-0003-0585-1026

Ralf Henkel iD https://orcid.org/0000-0003-1128-2982

\section{REFERENCES}

Agarwal, A., Ahmad, G., \& Sharma, R. (2015). Reference values of reactive oxygen species in seminal ejaculates using chemiluminescence assay. Journal of Assisted Reproduction and Genetics, 32(12), 17211729. https://doi.org/10.1007/s10815-015-0584-1

Agarwal, A., Allamaneni, S. S. R., Nallella, K. P., George, A. T., \& Mascha, E. (2005). Correlation of reactive oxygen species levels with the fertilization rate after in vitro fertilization: A qualified meta-analysis. Fertility and Sterility, 84(1), 228-231. https://doi.org/10.1016/j.fertn stert.2004.12.057

Agarwal, A., Bragais, F. M., \& Sabanegh, E. (2008). Assessing sperm function. Urologic Clinics of North America, 35(2), 157-171. https://doi. org/10.1016/j.ucl.2008.01.012

Agarwal, A., \& Bui, A. D. (2017). Oxidation-reduction potential as a new marker for oxidative stress: Correlation to male infertility. Investigative and Clinical Urology, 58(6), 385-399. https://doi.org/10.4111/icu.2017.58.6.385

Agarwal, A., Cho, C.-L., Majzoub, A., \& Esteves, S. C. (2017). The society for translational medicine: Clinical practice guidelines for sperm DNA fragmentation testing in male infertility. Translational Andrology and Urology, 6(Suppl 4), S720-S733. https://doi.org/10.21037/ tau.2017.08.06 
Agarwal, A., Cho, C.-L., \& Sharma, R. (2018). Laboratory evaluation of reactive oxygen species. In M.K. Skinner(Ed,). Encyclopedia of reproduction (pp. 78-84). https://doi.org/10.1016/ b978-0-12-801238-3.64841-9

Agarwal, A., Gupta, S., \& Sharma, R. (2016a). Acrosome reaction measurement. In A. Agarwal, S Gupta, \& R. Sharma(Eds,). Andrological evaluation of male infertility (pp. 143-146). Cham, Switzerland: Springer.

Agarwal, A., Gupta, S., \& Sharma, R. (2016b). Hypoosmotic swelling test (HOS). In A. Agarwal, S Gupta, \& R. Sharma(Eds,). Andrological evaluation of male infertility (pp. 93-96). Cham, Switzerland: Springer.

Agarwal, A., Henkel, R., Sharma, R., Tadros, N. N., \& Sabanegh, E. (2018). Determination of seminal oxidation-reduction potential (ORP) as an easy and cost-effective clinical marker of male infertility. Andrologia, 50(3), e12914. https://doi.org/10.1111/and.12914

Agarwal, A., \& Majzoub, A. (2017). Laboratory tests for oxidative stress. Indian Journal of Urology, 33(3), 199-206. https://doi.org/10.4103/ iju.IJU_9_17

Agarwal, A., Mulgund, A., Sharma, R., \& Sabanegh, E. (2014). Mechanisms of oligozoospermia: An oxidative stress perspective. Systems Biology in Reproductive Medicine, 60(4), 206-216. https://doi. org/10.3109/19396368.2014.918675

Agarwal, A., Panner Selvam, M. K., Arafa, M., Okada, H., Homa, S., Killeen, A., ... Sikka, S. (2019). Multi-center evaluation of oxidation-reduction potential by the MiOXSYS in males with abnormal semen. Asian Journal of Andrology, 21(6), 565-569. https://doi.org/10.4103/aja.aja_5_19

Agarwal, A., \& Said, T. M. (2009). Tests for sperm antibodies. In K.H.Walter, Krause, \& K. N. Rajesh(Eds,). Immune infertility: The impact of immune reactions on human infertility (pp. 155-164).

Agarwal, A., Sharma, R. K., Sharma, R., Assidi, M., Abuzenadah, A. M., Alshahrani, S., ... Sabanegh, E. (2014). Characterizing semen parameters and their association with reactive oxygen species in infertile men. Reproductive Biology and Endocrinology, 12(1), 33. https://doi. org/10.1186/1477-7827-12-33

Agarwal, A., Virk, G., Ong, C., \& du Plessis, S. S. (2014). Effect of oxidative stress on male reproduction. The World Journal of Men's Health, 32(1), 1. https://doi.org/10.5534/wjmh.2014.32.1.1

Aitken, R. J. (2017). Reactive oxygen species as mediators of sperm capacitation and pathological damage. Molecular Reproduction and Development, 84(10), 1039-1052. https://doi.org/10.1002/ $\operatorname{mrd} .22871$

Aitken, R. J., \& Baker, H. W. G. (1995). Andrology: Seminal leukocytes: Passengers, terrorists or good samaritans? Human Reproduction, 10(7), 1736-1739. https://doi.org/10.1093/oxfordjournals.humrep. a136165

Aitken, R. J., Buckingham, D. W., \& West, K. M. (1992). Reactive oxygen species and human spermatozoa: Analysis of the cellular mechanisms involved in luminol- and lucigenin-dependent chemiluminescence. Journal of Cellular Physiology, 151(3), 466-477. https://doi. org/10.1002/jcp.1041510305

Aitken, R. J., Gibb, Z., Baker, M. A., Drevet, J., \& Gharagozloo, P. (2016). Causes and consequences of oxidative stress in spermatozoa. Reproduction, Fertility and Development, 28(2), 1-10. https://doi. org/10.1071/RD15325

Ajina, T., Ammar, O., Haouas, Z., Sallem, A., Ezzi, L., Grissa, I., ... Mehdi, M. (2017). Assessment of human sperm DNA integrity using two cytochemical tests: Acridine orange test and toluidine blue assay. Andrologia, 49(10), e12765. https://doi.org/10.1111/and.12765

Alshahrani, S., Agarwal, A., Assidi, M., Abuzenadah, A. M., Durairajanayagam, D., Ayaz, A., ... Sabanegh, E. (2014). Infertile men older than 40 years are at higher risk of sperm DNA damage. Reproductive Biology and Endocrinology, 12, 103. https://doi. org/10.1186/1477-7827-12-103

Alvarez, J. G., Sharma, R. K., Ollero, M., Saleh, R. A., Lopez, M. C., Thomas, A. J., ... Agarwal, A. (2002). Increased DNA damage in sperm from leukocytospermic semen samples as determined by the sperm chromatin structure assay. Fertility and Sterility, 78(2), 319-329. https:// doi.org/10.1016/S0015-0282(02)03201-6

Anifandis, G., Messini, C., Dafopoulos, K., Sotiriou, S., \& Messinis, I. (2014). Molecular and cellular mechanisms of sperm-oocyte interactions opinions relative to in vitro fertilization (IVF). International Journal of Molecular Sciences, 15(7), 12972-12997. https://doi. org/10.3390/ijms150712972

Arafa, M., Agarwal, A., Al Said, S., Majzoub, A., Sharma, R., Bjugstad, K. B., ... Elbardisi, H. (2018). Semen quality and infertility status can be identified through measures of oxidation-reduction potential. Andrologia, 50(2), e12881. https://doi.org/10.1111/and.12881

Arnon, J., Meirow, D., Lewis-Roness, H., \& Ornoy, A. (2001). Genetic and teratogenic effects of cancer treatments on gametes and embryos. Human Reproduction Update, 7(4), 394-403. https://doi.org/10.1093/ humupd/7.4.394

Arslan, M., Morshedi, M., Ozturk Arslan, E., Taylor, S., Kanik, A., Duran, H. E., \& Oehninger, S. (2006). Predictive value of the hemizona assay for pregnancy outcome in patients undergoing controlled ovarian hyperstimulation with intrauterine insemination. Fertility and Sterility, 85(6), 1697-1707. https://doi.org/10.1016/j.fertnstert.2005.11.054

Ayaz, A., Agarwal, A., Sharma, R., Arafa, M., Elbardisi, H., \& Cui, Z. (2015). Impact of precise modulation of reactive oxygen species levels on spermatozoa proteins in infertile men. Clinical Proteomics, 12(1), 4. https://doi.org/10.1186/1559-0275-12-4

Barratt, C. L. R., Osborn, J. C., Harrison, P. E., Monks, N., Dunphy, B. C., Lenton, E. A., \& Cooke, I. D. (1989). The hypo-osmotic swelling test and the sperm mucus penetration test in determining fertilization of the human oocyte. Human Reproduction, 4(4), 430-434. https://doi. org/10.1093/oxfordjournals.humrep.a136922

Bastiaan, H. S., Menkveld, R., Oehninger, S., \& Franken, D. R. (2002). Zona pellucida induced acrosome reaction, sperm morphology, and sperm-zona binding assessments among subfertile men. Journal of Assisted Reproduction and Genetics, 19(7), 329-334. https://doi. org/10.1023/a:1016058625874

Benchaib, M., Lornage, J., Mazoyer, C., Lejeune, H., Salle, B., \& François Guerin, J. (2007). Sperm deoxyribonucleic acid fragmentation as a prognostic indicator of assisted reproductive technology outcome. Fertility and Sterility, 87(1), 93-100. https://doi.org/10.1016/j.fertn stert.2006.05.057

Berger, G. K., Smith-Harrison, L. I., \& Sandlow, J. I. (2019). Sperm agglutination: Prevalence and contributory factors. Andrologia, 51(5), e13254. https://doi.org/10.1111/and.13254

Boe-Hansen, G. B., Ersbøll, A. K., \& Christensen, P. (2005). Variability and laboratory factors affecting the sperm chromatin structure assay in human semen. Journal of Andrology, 26(3), 360-368. https://doi. org/10.2164/jandrol.04056

Borini, A., Tarozzi, N., Bizzaro, D., Bonu, M. A., Fava, L., Flamigni, C., \& Coticchio, G. (2006). Sperm DNA fragmentation: Paternal effect on early post-implantation embryo development in ART. Human Reproduction, 21(11), 2876-2881. https://doi.org/10.1093/humrep/ del251

Bungum, M., Humaidan, P., Axmon, A., Spano, M., Bungum, L., Erenpreiss, J., \& Giwercman, A. (2007). Sperm DNA integrity assessment in prediction of assisted reproduction technology outcome. Human Reproduction, 22(1), 174-179. https://doi.org/10.1093/humrep/del326

Cebesoy, F. B., Aydos, K., \& Unlu, C. (2006). Effect of sperm chromatin damage on fertilization ratio and embryo quality post-ICSI. Archives of Andrology, 52(5), 397-402. https://doi.org/10.1080/0148501060 0666953

Chiu, W. W. C., \& Chamley, L. W. (2004). Clinical associations and mechanisms of action of antisperm antibodies. Fertility and Sterility, 82(3), 529-535. https://doi.org/10.1016/j.fertnstert.2003.09.084

Cissen, M., Wely, M. V., Scholten, I., Mansell, S., Bruin, J. P. D., Mol, B. W., ... Hamer, G. (2016). Measuring sperm DNA fragmentation and 
clinical outcomes of medically assisted reproduction: A systematic review and meta-analysis. PLoS ONE, 11, e0165125. https://doi. org/10.1371/journal.pone.0165125

Cui, D., Han, G., Shang, Y., Liu, C., Xia, L., Li, L., \& Yi, S. (2015). Antisperm antibodies in infertile men and their effect on semen parameters: $A$ systematic review and meta-analysis. Clinica Chimica Acta, 444, 2936. https://doi.org/10.1016/j.cca.2015.01.033

Cui, Z. L., Zheng, D. Z., Liu, Y. H., Chen, L. Y., Lin, D. H., \& Lan, F. H. (2015). Diagnostic accuracies of the TUNEL, SCD, and comet based sperm DNA fragmentation assays for male infertility: A meta-analysis study. Clinical Laboratory, 61(5-6), 525-535. https://doi.org/10.7754/Clin. Lab.2014.141005

De Almeida, M., Soumah, A., \& Jouannet, P. (1986). Incidence of sperm-associated immunoglobulins in infertile men with suspected autoimmunity to sperm. International Journal of Andrology, 9(5), 321330. https://doi.org/10.1111/j.1365-2605.1986.tb00894.x

de Castro, L. S., de Assis, P. M., Siqueira, A. F. P., Hamilton, T. R. S., Mendes, C. M., Losano, J. D. A., ... Assumpção, M. E. O. A. (2016). Sperm oxidative stress is detrimental to embryo development: A dose-dependent study model and a new and more sensitive oxidative status evaluation. Oxidative Medicine and Cellular Longevity, 2016, 8213071. https://doi.org/10.1155/2016/8213071

de Lamirande, E., Leduc, B. E., Iwasaki, A., Hassouna, M., \& Gagnon, C. (1995). Increased reactive oxygen species formation in semen of patients with spinal cord injury. Fertility and Sterility, 63(3), 637-642. https://doi.org/10.1016/S0015-0282(16)57438-X

Dias, T. R., Cho, C.-L., \& Agarwal, A. (2019). Sperm assessment: Traditional approaches and their indicative value. In Z.P. Nagy, A.C. Varghese, \& A. Agarwal(Eds,). In vitro fertilization (pp. 249-263). New York, NY: Springer International Publishing.

Dolník, M., Mudroňová, D., Pošivák, J., Lazar, G., \& Mudroň, P. (2019). Flow cytometry in assessment of sperm integrity and functionality - A review. Acta Veterinaria Brno, 88(2), 169-175. https://doi. org/10.2754/avb201988020169

Du Plessis, S. S., Agarwal, A., Halabi, J., \& Tvrda, E. (2015). Contemporary evidence on the physiological role of reactive oxygen species in human sperm function. Journal of Assisted Reproduction and Genetics, 32(4), 509-520. https://doi.org/10.1007/s10815-014-0425-7

Durairajanayagam, D. (2018). Lifestyle causes of male infertility. Arab Journal of Urology, 16(1), 10-20. https://doi.org/10.1016/j. aju.2017.12.004

Elbardisi, H., Majzoub, A., Al Said, S., Al Rumaihi, K., El Ansari, W., Alattar, A., \& Arafa, M. (2018). Geographical differences in semen characteristics of 13892 infertile men. Arab Journal of Urology, 16(1), 3-9. https://doi.org/10.1016/j.aju.2017.11.018

El-Taieb, M. A., Ali, M. A., \& Nada, E. A. (2015). Oxidative stress and acrosomal morphology: A cause of infertility in patients with normal semen parameters. Middle East Fertility Society Journal, 20(2), 79-85. https://doi.org/10.1016/j.mefs.2014.05.003

Enciso, M., Sarasa, J., Agarwal, A., Fernández, J. L., \& Gosálvez, J. (2009). A two-tailed Comet assay for assessing DNA damage in spermatozoa. Reproductive BioMedicine Online, 18(5), 609-616. https://doi. org/10.1016/S1472-6483(10)60003-X

Erenpreisa, J., Erenpreiss, J., Freivalds, T., Slaidina, M., Krampe, R., Butikova, J., ... Pjanova, D. (2003). Toluidine blue test for sperm DNA integrity and elaboration of image cytometry algorithm. Cytometry, 52A(1), 19-27. https://doi.org/10.1002/cyto.a.10015

Esfandiari, N., Sharma, R. K., Saleh, R. A., Thomas, A. J., \& Agarwal, A. (2003). Utility of the nitroblue tetrazolium reduction test for assessment of reactive oxygen species production by seminal leukocytes and spermatozoa. Journal of Andrology, 24(6), 862-870. https://doi. org/10.1002/j.1939-4640.2003.tb03137.x

Espinoza, J. A., Schulz, M. A., Sánchez, R., \& Villegas, J. V. (2009). Integrity of mitochondrial membrane potential reflects human sperm quality. Andrologia, 41(1), 51-54. https://doi.org/10.1111/j.1439-0272.2008.00878.x
Esteves, S. C. (2014). Clinical relevance of routine semen analysis and controversies surrounding the 2010 World Health Organization criteria for semen examination. International Brazilian Journal of Urology, 40(4), 443-453. https://doi.org/10.1590/S1677-5538. IBJU.2014.04.02

Esteves, S. C., Verza, S., Sharma, R. K., Gosálvez, J., \& Agarwal, A. (2015). Role and significance of sperm function in men with unexplained infertility. In G. L. Schattman, S. C. Esteves, \& A. Agarwal(Eds,). Unexplained infertility: Pathophysiology, evaluation and treatment (pp. 91-119). New York, NY: Springer.

Evans, J. P., \& Bailey, J. L. (2010). How does the sperm make its way to the egg and how does fertilization take place? In B. Robaire, P. Chan(Eds,). Handbook of andrology (2nd ed., pp. 15-1-15-5). Lawrence, KS: Allen Press.

Evenson, D. P. (2013). Sperm chromatin structure assay (SCSA $®$ ). Methods in Molecular Biology, 927, 147-164. https://doi.org/10.1007/978-162703-38-0_14

Evenson, D. P. (2016). The Sperm Chromatin Structure Assay (SCSA $®$ ) and other sperm DNA fragmentation tests for evaluation of sperm nuclear DNA integrity as related to fertility. Animal Reproduction Science, 169, 56-75. https://doi.org/10.1016/j.anireprosci.2016.01.017

Evenson, D. P., Jost, L. K., Corzett, M., \& Balhorn, R. (2000). Characteristics of human sperm chromatin structure following an episode of influenza and high fever: A case study. Journal of Andrology, 21(5), 739746. https://doi.org/10.1002/j.1939-4640.2000.tb02142.x

Evenson, D. P., Kasperson, K., \& Wixon, R. L. (2007). Analysis of sperm DNA fragmentation using flow cytometry and other techniques. Society of Reproduction and Fertility Supplement, 65, 93-113.

García-Macías, V., Martínez-Pastor, F., Martínez, F., González, N., Álvarez, M., Anel, E., ... Anel, L. (2005). Problems using JC-1 to assess mitochondrial status in brown bear (Ursus arctos) semen. Reproduction, Fertility and Development, 17(2), 246. https://doi.org/10.1071/rdv17 n2ab192

Gosálvez, J., López-Fernández, C., \& Fernández, J. L. (2013). Sperm chromatin dispersion test: Technical aspects and clinical applications. In A. Zini, A. Agarwal(Eds,). Sperm chromatin for the researcher (pp. 257-281). New York, NY: Springer.

Gosálvez, J., Tvrda, E., \& Agarwal, A. (2017). Free radical and superoxide reactivity detection in semen quality assessment: Past, present, and future. Journal of Assisted Reproduction and Genetics, 34(6), 697-707. https://doi.org/10.1007/s10815-017-0912-8

Green, K. A., Patounakis, G., Dougherty, M. P., Werner, M. D., Scott, R. T., \& Franasiak, J. M. (2019). Sperm DNA fragmentation on the day of fertilization is not associated with embryologic or clinical outcomes after IVF/ICSI. Journal of Assisted Reproduction and Genetics, 37(1), 71-76. https://doi.org/10.1007/s10815-019-01632-5

Gunes, S., Al-Sadaan, M., \& Agarwal, A. (2015). Spermatogenesis, DNA damage and DNA repair mechanisms in male infertility. Reproductive BioMedicine Online, 31(3), 309-319. https://doi.org/10.1016/j. rbmo.2015.06.010

Gupta, S., Caraballo, M., \& Agarwal, A. (2019). Total antioxidant capacity measurement by colorimetric assay. In R. Henkel, L. Samanta, \& A. Agarwal(Eds,). Oxidants, antioxidants and impact of the oxidative status in male reproduction (pp. 207-215). Cambridge, MA: Academic Press.

Hamada, A., Esteves, S. C., \& Agarwal, A. (2011). Unexplained male infertility. Human Andrology, 1(1), 2-16. https://doi.org/10.1097/01. xha.0000397686.82729.09

Henkel, R. (2007). Detection of DNA damage in sperm. In T. F. Kruger, \& S. Oehninger (Eds.), Male infertility: Diagnosis and treatment (pp. 225-238). London, UK: Informa UK Ltd.

Henkel, R., Hoogendijk, C. F., Bouic, P. J. D., \& Kruger, T. F. (2010). TUNEL assay and SCSA determine different aspects of sperm DNA damage. Andrologia, 42(5), 305-313. https://doi. org/10.1111/j.1439-0272.2009.01002.x 
Henkel, R., Kierspel, E., Hajimohammad, M., Stalf, T., Hoogendijk, C., Mehnert, C., ... Kruger, T. F. (2003). DNA fragmentation of spermatozoa and assisted reproduction technology. Reproductive BioMedicine Online, 7(4), 477-484. https://doi.org/10.1016/S1472 -6483(10)61893-7

Henkel, R., Müller, C., Miska, W., Gips, H., \& Schill, W. B. (1993). Fertilization and early embryology: Determination of the acrosome reaction in human spermatozoa is predictive of fertilization in vitro. Human Reproduction, 8(12), 2128-2132. https://doi.org/10.1093/ oxfordjournals.humrep.a137994

Henkel, R., Cooper, S., Kaskar, K., Schill, W-B., Habenicht, U-F., \& Franken, D. R. (1995). Influence of elevated $\mathrm{pH}$ levels on structural and functional characteristics of the human zona pellucida: Functional morphological aspects. J Assist Reprod Genet, 12, 644-649.

Henkel, R., Müller, C., Stalf, T., Schill, W. B., \& Franken, D. R. (1999). Use of failed-fertilized oocytes for diagnostic zona binding purposes after sperm binding improvement with a modified medium. Journal of Assisted Reproduction and Genetics, 16(1), 24-29. https://doi. org/10.1023/A:1022541511875

Henkel, R., Sandhu, I. S., \& Agarwal, A. (2019). The excessive use of antioxidant therapy: A possible cause of male infertility? Andrologia, 51(1), e13162. https://doi.org/10.1111/and.13162

Hossain, M. S., Johannisson, A., Wallgren, M., Nagy, S., Siqueira, A. P., \& Rodriguez-Martinez, H. (2011). Flow cytometry for the assessment of animal sperm integrity and functionality: State of the art. Asian Journal of Andrology, 13(3), 406-419. https://doi.org/10.1038/aja.2011.15

Huszar, G., Ozenci, C. C., Cayli, S., Zavaczki, Z., Hansch, E., \& Vigue, L. (2003). Hyaluronic acid binding by human sperm indicates cellular maturity, viability, and unreacted acrosomal status. Fertility and Sterility, 79(Suppl 3), 1616-1624. https://doi.org/10.1016/S0015 -0282(03)00402-3

Ikawa, M., Inoue, N., Benham, A. M., \& Okabe, M. (2010). Fertilization: A sperm's journey to and interaction with the oocyte. Journal of Clinical Investigation, 120(4), 984-994. https://doi.org/10.1172/JCl41585

Iranpour, F. G., Nasr-Esfahani, M. H., Valojerdi, M. R., \& Taki Al-Taraihi, T. M. (2000). Chromomycin A3 staining as a useful tool for evaluation of male fertility. Journal of Assisted Reproduction and Genetics, 17(1), 60-66. https://doi.org/10.1023/A:1009406231811

Irvine, D. S., Twigg, J. P., Gordon, E. L., Fulton, N., Milne, P. A., \& Aitken, R. J. (2000). DNA integrity in human spermatozoa: Relationships with semen quality. Journal of Andrology, 21(1), 33-44. https://doi. org/10.1002/j.1939-4640.2000.tb03273.x

Jeyendran, R., Van der Ven, H., Perez-Pelaez, M., Crabo, B., \& Zaneveld, L. (1984). Development of an assay to assess the functional integrity of the human sperm membrane and its relationship to other semen characteristics. Journal of Reproduction and Fertility, 70(1), 219-228. https://doi.org/10.1530/jrf.0.0700219

Jurewicz, J., Hanke, W., Radwan, M., \& Bonde, J. (2009). Environmental factors and semen quality. International Journal of Occupational Medicine and Environmental Health, 22(4), 305-329. https://doi. org/10.2478/v10001-009-0036-1

Kızılay, F., \& Altay, B. (2017). Sperm function tests in clinical practice. Turkish Journal of Urology, 43(4), 393-400. https://doi.org/10.5152/ tud.2017.96646

Kobayashi, H., Larson, K., Sharma, R. K., Nelson, D. R., Evenson, D. P., Toma, H., ... Agarwal, A. (2001). DNA damage in patients with untreated cancer as measured by the sperm chromatin structure assay. Fertility and Sterility, 75(3), 469-475. https://doi.org/10.1016/S0015 -0282(00)01740-4

Kvitko, D., Azambuja, R., Reig, V., De Martin, H., Badalotti, M., \& Petracco, A. (2012). Association between low motility and sperm DNA fragmentation despite sperm count in men. Fertility and Sterility, 98(3), S248-S249. https://doi.org/10.1016/j.fertnstert.2012.07.905

Le, M. T., Nguyen, T. A. T., Nguyen, H. T. T., Nguyen, T. T. T., Nguyen, V. T., Le, D. D., ... Cao, N. T. (2019). Does sperm DNA fragmentation

\section{ANDROLOGIa-WILEY}

correlate with semen parameters? Reproductive Medicine and Biology, 18(4), 390-396. https://doi.org/10.1002/rmb2.12297

Lewis, S. E. M. (2007). Is sperm evaluation useful in predicting human fertility? Reproduction, 134(1), 31-40. https://doi.org/10.1530/ REP-07-0152

Lewis, S. E. M., \& Aitken, R. J. (2005). DNA damage to spermatozoa has impacts on fertilization and pregnancy. Cell and Tissue Research, 322(1), 33-41. https://doi.org/10.1007/s00441-005-1097-5

Lewis, S. E. M., Aitken, R. J., Conner, S. J., Iuliis, G. D., Evenson, D. P., Henkel, R., ... Gharagozloo, P. (2013). The impact of sperm DNA damage in assisted conception and beyond: Recent advances in diagnosis and treatment. Reproductive BioMedicine Online, 27(4), 325-337. https://doi.org/10.1016/j.rbmo.2013.06.014

Liu, D. Y., \& Baker, H. W. G. (2000). Defective sperm-zona pellucida interaction: A major cause of failure of fertilization in clinical in-vitro fertilization. Human Reproduction, 15(3), 702-708. https://doi. org/10.1093/humrep/15.3.702

Liu, D. Y., \& Baker, H. W. G. (2004). High frequency of defective spermzona pellucida interaction in oligozoospermic infertile men. Human Reproduction, 19(2), 228-233. https://doi.org/10.1093/humrep/ deh067

Liu, D. Y., Clarke, G. N., Lopata, A., Johnston, W. I. H., \& Baker, H. W. G. (1989). A sperm-zona pellucida binding test and in vitro fertilization. Fertility and Sterility, 52(2), 281-287. https://doi.org/10.1016/S0015 -0282(16)60856-7

Liu, D. Y., Long, Y., Liu, M., Chen, X. L., Wu, W. Y., \& Cheng, J. E. (2014). Quality characteristics of human spermatozoa with hyaluronic acid receptors. Zhonghua Nan Ke Xue, 20(1), 37-43.

Lolis, D., Georgiou, I., Syrrou, M., Zikopoulos, K., Konstantelli, M., \& Messinis, I. (1996). Chromomycin A3-staining as an indicator of protamine deficiency and fertilization. International Journal of Andrology, 19(1), 23-27. https://doi.org/10.1111/j.1365-2605.1996.tb00429.x

López, G., Lafuente, R., Checa, M. A., Carreras, R., \& Brassesco, M. (2013). Diagnostic value of sperm DNA fragmentation and sperm high-magnification for predicting outcome of assisted reproduction treatment. Asian Journal of Andrology, 15(6), 790-794. https://doi. org/10.1038/aja.2013.81

Louis, J. F., Thoma, M. E., Sørensen, D. N., McLain, A. C., King, R. B., Sundaram, R., ... Buck Louis, G. M. (2013). The prevalence of couple infertility in the United States from a male perspective: Evidence from a nationally representative sample. Andrology, 1(5), 741-748. https://doi.org/10.1111/j.2047-2927.2013.00110.x

Mahfouz, R., Sharma, R., Lackner, J., Aziz, N., \& Agarwal, A. (2009). Evaluation of chemiluminescence and flow cytometry as tools in assessing production of hydrogen peroxide and superoxide anion in human spermatozoa. Fertility and Sterility, 92(2), 819-827. https://doi. org/10.1016/j.fertnstert.2008.05.087

Mahfouz, R., Sharma, R., Sharma, D., Sabanegh, E., \& Agarwal, A. (2009). Diagnostic value of the total antioxidant capacity (TAC) in human seminal plasma. Fertility and Sterility, 91(3), 805-811. https://doi. org/10.1016/j.fertnstert.2008.01.022

Mahfouz, R., Sharma, R., Thiyagarajan, A., Kale, V., Gupta, S., Sabanegh, E., \& Agarwal, A. (2010). Semen characteristics and sperm DNA fragmentation in infertile men with low and high levels of seminal reactive oxygen species. Fertility and Sterility, 94(6), 2141-2146. https:// doi.org/10.1016/j.fertnstert.2009.12.030

Majzoub, A., Arafa, M., Mahdi, M., Agarwal, A., Al Said, S., Al-Emadi, I., ... Elbardisi, H. (2018). Oxidation-reduction potential and sperm DNA fragmentation, and their associations with sperm morphological anomalies amongst fertile and infertile men. Arab Journal of Urology, 16(1), 87-95. https://doi.org/10.1016/j.aju.2017.11.014

Mao, C., \& Grimes, D. A. (1988). The sperm penetration assay: Can it discriminate between s fertile and infertile men? American Journal of Obstetrics and Gynecology, 159(2), 279-286. https://doi.org/10.1016/ S0002-9378(88)80068-1 
Martínez-Pastor, F., Mata-Campuzano, M., Álvarez-Rodríguez, M., Álvarez, M., Anel, L., \& de Paz, P. (2010). Probes and techniques for sperm evaluation by flow cytometry. Reproduction in Domestic Animals, 45(Suppl 2), 67-78. https://doi. org/10.1111/j.1439-0531.2010.01622.x

Mazumdar, S., \& Levine, A. S. (1998). Antisperm antibodies: Etiology, pathogenesis, diagnosis, and treatment. Fertility and Sterility, 70(5), 799-810. https://doi.org/10.1016/S0015-0282(98)00302-1

Meseguer, M., Santiso, R., Garrido, N., Gil-Salom, M., Remohí, J., \& Fernandez, J. L. (2009). Sperm DNA fragmentation levels in testicular sperm samples from azoospermic males as assessed by the sperm chromatin dispersion (SCD) test. Fertility and Sterility, 92(5), 16381645. https://doi.org/10.1016/j.fertnstert.2008.08.106

Mol, B. W., Meijer, S., Yuppa, S., Tan, E., de Vries, J., Bossuyt, P. M., \& van der Veen, F. (1998). Sperm penetration assay in predicting successful in vitro fertilization. A meta-analysis. The Journal of Reproductive Medicine, 43(6), 503-508.

Moody, M. A., Cardona, C., Simpson, A. J., Smith, T. T., Travis, A. J., \& Ostermeier, G. C. (2017). Validation of a laboratory-developed test of human sperm capacitation. Molecular Reproduction and Development, 84(5), 408-422. https://doi.org/10.1002/mrd.22801

Moradian Fard, Z., Naghdi, M., Salehi, P., Shahrokhi, S. Z., Ajami, A., Deemeh, M. R., \& Meshkibaf, M. H. (2019). SCSA results correlated with rate of motility reduction after ejaculation in Asthenozoospermia. Andrologia, 51(1), e13146. https://doi.org/10.1111/and.13146

Moraes, C. R., \& Meyers, S. (2018). The sperm mitochondrion: Organelle of many functions. Animal Reproduction Science, 194, 71-80. https:// doi.org/10.1016/j.anireprosci.2018.03.024

Morris, I. D. (2002). Sperm DNA damage and cancer treatment. International Journal of Andrology, 25(5), 255-261. https://doi. org/10.1046/j.1365-2605.2002.00372.x

Munuce, M., Berta, C., Pauluzzi, F., \& Caille, A. (2000). Relationship between antisperm antibodies, sperm movement, and semen quality. Urologia Internationalis, 65(4), 200-203. https://doi. org/10.1159/000064876

Muriel, L., Garrido, N., Fernández, J. L., Remohí, J., Pellicer, A., De Los Santos, M. J., \& Meseguer, M. (2006). Value of the sperm deoxyribonucleic acid fragmentation level, as measured by the sperm chromatin dispersion test, in the outcome of in vitro fertilization and intracytoplasmic sperm injection. Fertility and Sterility, 85(2), 371-383. https://doi.org/10.1016/j.fertnstert.2005.07.1327

Myles, D. G., \& Primakoff, P. (1997). Why did the sperm cross the cumulus? To get to the oocyte. Functions of the sperm surface proteins $\mathrm{PH}-20$ and fertilin in arriving at, and fusing with, the Egg1. Biology of Reproduction, 56(2), 320-327. https://doi.org/10.1095/biolreprod 56.2 .320

Nakamura, H., Kimura, T., Nakajima, A., Shimoya, K., Takemura, M., Hashimoto, K., ... Murata, Y. (2002). Detection of oxidative stress in seminal plasma and fractionated sperm from subfertile male patients. European Journal of Obstetrics and Gynecology and Reproductive Biology, 105(2), 155-160. https://doi.org/10.1016/ S0301-2115(02)00194-X

Nijs, M., Creemers, E., Cox, A., Franssen, K., Janssen, M., Vanheusden, E., ... Ombelet, W. (2009). Chromomycin A3 staining, sperm chromatin structure assay and hyaluronic acid binding assay as predictors for assisted reproductive outcome. Reproductive BioMedicine Online, 19(5), 671-684. https://doi.org/10.1016/j.rbmo.2009.07.002

Nijs, M., Creemers, E., Cox, A., Janssen, M., Vanheusden, E., Van Der Elst, J., \& Ombelet, W. (2010). Relationship between hyaluronic acid binding assay and outcome in ART: A pilot study. Andrologia, 42(5), 291-296. https://doi.org/10.1111/j.1439-0272.2009.00992.x

Oehninger, S. (2000). Sperm function assays and their predictive value for fertilization outcome in IVF therapy: A meta-analysis. Human Reproduction Update, 6(2), 160-168. https://doi.org/10.1093/humup $\mathrm{d} / 6.2 .160$
Oehninger, S., Coddington, C. C., Scott, R., Franken, D. A., Burkman, L. J., Acosta, A. A., \& Hodgen, G. D. (1989). Hemizona assay: Assessment of sperm dysfunction and prediction of in vitro fertilization outcome. Fertility and Sterility, 51(4), 665-670. https://doi.org/10.1016/S0015 -0282(16)60618-0

Oehninger, S., Franken, D. R., \& Ombelet, W. (2014). Sperm functional tests. Fertility and Sterility, 102(6), 1528-1533. https://doi. org/10.1016/j.fertnstert.2014.09.044

Oehninger, S., Veeck, L., Franken, D., Kruger, T. F., Acosta, A. A., \& Hodgen, G. D. (1991). Human preovulatory oocytes have a higher sperm-binding ability than immature oocytes under hemizona assay conditions: Evidence supporting the concept of "zona maturation". Fertility and Sterility, 55(6), 1165-1170. https://doi.org/10.1016/ s0015-0282(16)54369-6

Osman, A., Alsomait, H., Seshadri, S., El-Toukhy, T., \& Khalaf, Y. (2015). The effect of sperm DNA fragmentation on live birth rate after IVF or ICSI: A systematic review and meta-analysis. Reproductive BioMedicine Online, 30(2), 120-127. https://doi.org/10.1016/j. rbmo.2014.10.018

Pampiglione, J. S., Tan, S.-L., \& Campbell, S. (1994). The use of the stimulated acrosome reaction test as a test of fertilizing ability in human spermatozoa. International Journal of Gynecology \& Obstetrics, 44(2), 194-194. https://doi.org/10.1016/0020-7292(94)90107-4

Paoli, D., Pallotti, F., Lenzi, A., \& Lombardo, F. (2018). Fatherhood and sperm DNA damage in testicular cancer patients. Frontiers in Endocrinology, 9, 506. https://doi.org/10.3389/fendo.2018.00506

Patricio, A., Cruz, D. F., Silva, J. V., Padrão, A., Correia, B. R., KorrodiGregório, L., ... Fardilha, M. (2016). Relation between seminal quality and oxidative balance in sperm cells. Acta Urológica Portuguesa, 33(1), 6-15. https://doi.org/10.1016/j.acup.2015.10.001

Peeraer, K., Nijs, M., Raick, D., \& Ombelet, W. (2004). Pregnancy after ICSI with ejaculated immotile spermatozoa from a patient with immotile cilia syndrome: A case report and review of the literature. Reproductive BioMedicine Online, 9(6), 659-663. https://doi. org/10.1016/S1472-6483(10)61777-4

Perry, S. W., Norman, J. P., Barbieri, J., Brown, E. B., \& Gelbard, H. A. (2011). Mitochondrial membrane potential probes and the proton gradient: A practical usage guide. BioTechniques, 50(2), 98-115. https://doi.org/10.2144/000113610

Potts, R. J., Newbury, C. J., Smith, G., Notarianni, L. J., \& Jefferies, T. M. (1999). Sperm chromatin damage associated with male smoking. Mutation Research - Fundamental and Molecular Mechanisms of Mutagenesis, 423(1-2), 103-111. https://doi.org/10.1016/S0027 $-5107(98) 00242-5$

Pourmasumi, S., Sabeti, P., Rahiminia, T., Mangoli, E., Tabibnejad, N., \& Talebi, A. R. (2017). The etiologies of sperm DNA abnormalities in male infertility: An assessment and review. International Journal of Reproductive BioMedicine, 15(6), 331-344. https://doi.org/10.29252 /ijrm.15.6.331

Ribas-Maynou, J., García-Peiró, A., Fernández-Encinas, A., Abad, C., Amengual, M. J., Prada, E., ... Benet, J. (2013). Comprehensive analysis of sperm DNA fragmentation by five different assays: TUNEL assay, SCSA, SCD test and alkaline and neutral Comet assay. Andrology, 1(5), 715-722. https://doi. org/10.1111/j.2047-2927.2013.00111.x

Ribeiro, S., Sharma, R., Gupta, S., Cakar, Z., De Geyter, C., \& Agarwal, A. (2017). Inter- and intra-laboratory standardization of TUNEL assay for assessment of sperm DNA fragmentation. Andrology, 5(3), 477485. https://doi.org/10.1111/andr.12334

Rossato, M., Galeazzi, C., Ferigo, M., \& Foresta, C. (2004). Antisperm antibodies modify plasma membrane functional integrity and inhibit osmosensitive calcium influx in human sperm. Human Reproduction, 19(8), 1816-1820. https://doi.org/10.1093/humrep/deh317

Roychoudhury, S., Sharma, R., Sikka, S., \& Agarwal, A. (2016). Diagnostic application of total antioxidant capacity in seminal plasma to 
assess oxidative stress in male factor infertility. Journal of Assisted Reproduction and Genetics, 33(5), 627-635. https://doi.org/10.1007/ s10815-016-0677-5

Sabeti, P., Pourmasumi, S., Rahiminia, T., Akyash, F., \& Talebi, A. R. (2016). Etiologies of sperm oxidative stress. International Journal of Reproductive BioMedicine, 14(4), 231-240. https://doi.org/10.29252/ijrm.14.4.231

Said, T. M., Kattal, N., Sharma, R. K., Sikka, S. C., Thomas, A. J., Mascha, E., \& Agarwal, A. (2003). Enhanced chemiluminescence assay vs colorimetric assay for measurement of the total antioxidant capacity of human seminal plasma. Journal of Andrology, 24(5), 676-680. https:// doi.org/10.1002/j.1939-4640.2003.tb02726.x

Sakkas, D., Urner, F., Bizzaro, D., Manicardi, G., Bianchi, P. G., Shoukir, Y., \& Campana, A. (1998). Sperm nuclear DNA damage and altered chromatin structure: Effect on fertilization and embryo development. Human Reproduction, 3(Suppl 4), 11-19. https://doi.org/10.1093/humrep/13. suppl_4.11

Saleh, R. A., Agarwal, A., Nada, E. A., El-Tonsy, M. H., Sharma, R. K., Meyer, A., ... Thomas, A. J. (2003). Negative effects of increased sperm DNA damage in relation to seminal oxidative stress in men with idiopathic and male factor infertility. Fertility and Sterility, 79(Suppl 3), 15971605. https://doi.org/10.1016/S0015-0282(03)00337-6

Saleh, R. A., Agarwal, A., Sharma, R. K., Said, T. M., Sikka, S. C., \& Thomas, A. J. (2003). Evaluation of nuclear DNA damage in spermatozoa from infertile men with varicocele. Fertility and Sterility, 80(6), 1431-1436. https://doi.org/10.1016/S0015-0282(03)02211-8

Samplaski, M. K., Agarwal, A., Sharma, R., \& Sabanegh, E. (2010). New generation of diagnostic tests for infertility: Review of specialized semen tests. International Journal of Urology, 17(10), 839-847. https://doi.org/10.1111/j.1442-2042.2010.02619.x

Samplaski, M. K., Sharma, R., Agarwal, A., \& Sabanegh, E. (2014). Testing beyond the semen analysis: The evolving role of new tests. In B. Rizk, N. Aziz, A. Agarwal, \& E. Sabanegh(Eds,). Medical \& Surgical Management of Male Infertility(pp. 56-62). New Delhi, India: Jaypee Digital.

Schinfeld, J., Sharara, F., Morris, R., Palermo, G. D., Rosenwaks, Z. Seaman, E., ... Travis, A. J. (2018). Cap-Score ${ }^{\mathrm{TM}}$ prospectively predicts probability of pregnancy. Molecular Reproduction and Development, 85(8-9), 654-664. https://doi.org/10.1002/mrd.23057

Schlegel, P. N., \& Paduch, D. A. (2005). Yet another test of sperm chromatin structure. Fertility and Sterility, 84(4), 854-859. https://doi. org/10.1016/j.fertnstert.2005.04.050

Schulte, R. T., Ohl, D. A., Sigman, M., \& Smith, G. D. (2010). Sperm DNA damage in male infertility: Etiologies, assays, and outcomes. Journal of Assisted Reproduction and Genetics, 27(1), 3-12. https://doi. org/10.1007/s10815-009-9359-x

Sharma, R., Ahmad, G., Esteves, S. C., \& Agarwal, A. (2016). Terminal deoxynucleotidyl transferase dUTP nick end labeling (TUNEL) assay using bench top flow cytometer for evaluation of sperm DNA fragmentation in fertility laboratories: Protocol, reference values, and quality control. Journal of Assisted Reproduction and Genetics, 33(2), 291-300. https://doi.org/10.1007/s10815-015-0635-7

Sharma, R. K., Panner Selvam, M. K., \& Agarwal, A. (2019). Reactive oxygen species methodology using chemiluminescence assay. In R Henkel, L. Samanta, \& A. Agarwal(Eds,). Oxidants, antioxidants and impact of the oxidative status in male reproduction (pp. 183-193). Amsterdam, The Netherlands: Elsevier.

Sharma, R. K., Sabanegh, E., Mahfouz, R., Gupta, S., Thiyagarajan, A., \& Agarwal, A. (2010). TUNEL as a test for sperm DNA damage in the evaluation of male infertility. Urology, 76(6), 1380-1386. https://doi. org/10.1016/j.urology.2010.04.036

Sigman, M., \& Zini, A. (2009). Semen analysis and sperm function assays: What do they mean? Seminars in Reproductive Medicine, 27(2), 115123. https://doi.org/10.1055/s-0029-1202300

Simon, L., \& Carrell, D. T. (2013). Sperm DNA damage measured by comet assay. Methods in Molecular Biology, 927, 137-146. https://doi. org/10.1007/978-1-62703-038-0_13
Simon, L., Castillo, J., Oliva, R., \& Lewis, S. E. M. (2011). Relationships between human sperm protamines, DNA damage and assisted reproduction outcomes. Reproductive BioMedicine Online, 23(6), 724-734. https://doi.org/10.1016/j.rbmo.2011.08.010

Simon, L., Lutton, D., McManus, J., \& Lewis, S. E. M. (2011). Sperm DNA damage measured by the alkaline Comet assay as an independent predictor of male infertility and in vitro fertilization success. Fertility and Sterility, 95(2), 652-657. https://doi.org/10.1016/j.fertn stert.2010.08.019

Simon, L., Proutski, I., Stevenson, M., Jennings, D., McManus, J., Lutton, D., \& Lewis, S. E. M. (2013). Sperm DNA damage has a negative association with live-birth rates after IVF. Reproductive BioMedicine Online, 26(1), 68-78. https://doi.org/10.1016/j.rbmo.2012.09.019

Singh, A., \& Agarwal, A. (2011). The role of sperm chromatin integrity and DNA damage on male infertility. The Open Reproductive Science Journal, 3(1), 65-71.

Singh, N. P., McCoy, M. T., Tice, R. R., \& Schneider, E. L. (1988). A simple technique for quantitation of low levels of DNA damage in individual cells. Experimental Cell Research, 175(1), 184-191. https://doi. org/10.1016/0014-4827(88)90265-0

Sinisi, A. A., Finizio, B. D., Pasquali, D., Scurini, C., D'apuzzo, A., \& Bellastella, A. (1993). Prevalence of antisperm antibodies by SpermMARtest in subjects undergoing a routine sperm analysis for infertility. International Journal of Andrology, 16(5), 311-314. https:// doi.org/10.1111/j.1365-2605.1993.tb01197.x

Snow-Lisy, D., \& Sabanegh, E. (2013). What does the clinician need from an andrology laboratory? Frontiers in Biosciences, 5, 289-304. https:// doi.org/10.2741/E616

Stanger, J. D., Vo, L., Yovich, J. L., \& Almahbobi, G. (2010). Hypo-osmotic swelling test identifies individual spermatozoa with minimal DNA fragmentation. Reproductive BioMedicine Online, 21, 474-484. https://doi.org/10.1016/j.rbmo.2010.06.026

Sun, J.-G., Jurisicova, A., \& Casper, R. F. (1997). Detection of deoxyribonucleic acid fragmentation in human sperm: Correlation with fertilization in vitro1. Biology of Reproduction, 56(3), 602-607. https://doi. org/10.1095/biolreprod56.3.602

Tarozzi, N., Nadalini, M., Bizzaro, D., Serrao, L., Fava, L., Scaravelli, G., \& Borini, A. (2009). Sperm-hyaluronan-binding assay: Clinical value in conventional IVF under Italian law. Reproductive BioMedicine Online, 19(Suppl 3), 35-43. https://doi.org/10.1016/S1472-6483(10)60282 $-9$

Tartagni, M., Schonauer, M. M., Cicinelli, E., Selman, H., De Ziegler, D., Petruzzelli, F., \& D'Addario, V. (2002). Usefulness of the hypo-osmotic swelling test in predicting pregnancy rate and outcome in couples undergoing intrauterine insemination. Journal of Andrology, 23(4), 498-502. https://doi.org/10.1002/j.1939-4640.2002.tb022 71.x

Tavilani, H., Doosti, M., \& Saeidi, H. (2005). Malondialdehyde levels in sperm and seminal plasma of asthenozoospermic and its relationship with semen parameters. Clinica Chimica Acta, 356(1-2), 199-203. https://doi.org/10.1016/j.cccn.2005.01.017

Trisini, A. T., Singh, N. P., Duty, S. M., \& Hauser, R. (2004). Relationship between human semen parameters and deoxyribonucleic acid damage assessed by the neutral comet assay. Fertility and Sterility, 82(6), 1623-1632. https://doi.org/10.1016/j.fertnstert.2004.05.087

Tsarev, I., Bungum, M., Giwercman, A., Erenpreisa, J., Ebessen, T., Ernst, E., \& Erenpreiss, J. (2009). Evaluation of male fertility potential by Toluidine Blue test for sperm chromatin structure assessment. Human Reproduction, 24(7), 1569-1574. https://doi.org/10.1093/ humrep/dep068

Uribe, P., Villegas, J. V., Boguen, R., Treulen, F., Sánchez, R., Mallmann, P., ... Isachenko, E. (2017). Use of the fluorescent dye tetramethylrhodamine methyl ester perchlorate for mitochondrial membrane potential assessment in human spermatozoa. Andrologia, 49(9), e12753. https://doi.org/10.1111/and.12753 
Vasan, S. S. (2011). Semen analysis and sperm function tests: How much to test. Indian Journal of Urology, 27(1), 41-48. https://doi. org/10.4103/0970-1591.78424

Velez de la Calle, J. F., Muller, A., Walschaerts, M., Clavere, J. L., Jimenez, C., Wittemer, C., \& Thonneau, P. (2008). Sperm deoxyribonucleic acid fragmentation as assessed by the sperm chromatin dispersion test in assisted reproductive technology programs: Results of a large prospective multicenter study. Fertility and Sterility, 90(5), 1792-1799. https://doi.org/10.1016/j.fertnstert.2007.09.021

Vessey, W., Perez-Miranda, A., Macfarquhar, R., Agarwal, A., \& Homa, S. (2014). Reactive oxygen species in human semen: Validation and qualification of a chemiluminescence assay. Fertility and Sterility, 102(6), 1576-1583.e4. https://doi.org/10.1016/j.fertnstert.2014.09.009

Vogiatzi, P., Chrelias, C., Cahill, D. J., Creatsa, M., Vrachnis, N. Iliodromiti, Z., ... Siristatidis, C. (2013). Hemizona assay and sperm penetration assay in the prediction of IVF outcome: A systematic review. BioMed Research International, 2013, 1-10. https://doi. org/10.1155/2013/945825

Wallach, E. E., Moghissi, K. S., \& Wallach, E. E. (1983). Unexplained infertility. Fertility and Sterility, 39(1), 5-21. https://doi.org/10.1016/ s0015-0282(16)46750-6

Wang, J.-X., Han, M.-T., Shen, L.-Y., Wang, G.-G., Cheng, H.-B., Yang, S.-M., ... Shi, Y.-C. (2017). [Sperm chromatin structure assay versus sperm chromatin dispersion test in detecting sperm DNA integrity and correlation of sperm DNA fragmentation with semen parameters]. Zhonghua Nan Ke Xue, 23(4), 329-336.

Wiweko, B., \& Utami, P. (2017). Predictive value of sperm deoxyribonucleic acid (DNA) fragmentation index in male infertility. Basic and Clinical Andrology, 27(1), 1. https://doi.org/10.1186/s1261 0-016-0046-3

World Health Organization, Department of Reproductive Health and Research. (2010). Laboratory manual for the examination and processing of human semen. 5thedn. (pp. 287). Geneva, Switzerland: WHO Press

Yuan, M., Huang, L., Leung, W. T., Wang, M., Meng, Y. I., Huang, Z., ... Wang, L. (2019). Sperm DNA fragmentation valued by SCSA and its correlation with conventional sperm parameters in male partner of recurrent spontaneous abortion couple. BioScience Trends, 13(2), 152-159. https://doi.org/10.5582/bst.2018.01292

Zarghami, N., \& Khosrowbeygi, A. (2004). Evaluation of lipid peroxidation as an indirect measure of oxidative stress in seminal plasma. Iranian Journal of Reproductive Medicine, 2(1), 34.

Zeginiadou, T., Papadimas, J., \& Mantalenakis, S. (2000). Acrosome reaction: Methods for detection and clinical significance. Andrologia, 32(6), 335-343. https://doi.org/10.1046/j.1439-0272.2000.00359.x

Zini, A., Bielecki, R., Phang, D., \& Zenzes, M. T. (2001). Correlations between two markers of sperm DNA integrity, DNA denaturation and DNA fragmentation, in fertile and infertile men. Fertility and Sterility, 75(4), 674-677. https://doi.org/10.1016/S0015-0282(00)01796-9

Zini, A., \& Libman, J. (2006). Sperm DNA damage: Clinical significance in the era of assisted reproduction. Canadian Medical Association Journal, 175(5), 495-500. https://doi.org/10.1503/cmaj.060218

Zou, T., Liu, X., Ding, S., \& Xing, J. (2010). Evaluation of sperm mitochondrial function using rh123/PI dual fluorescent staining in asthenospermia and oligoasthenozoospermia. Journal of Biomedical Research, 24(5), 404-410. https://doi.org/10.1016/S1674-8301(10)60054-1

How to cite this article: Barbăroșie C, Agarwal A, Henkel R. Diagnostic value of advanced semen analysis in evaluation of male infertility. Andrologia. 2021;53:e13625. https://doi. org/10.1111/and.13625 